University of Nebraska - Lincoln

DigitalCommons@University of Nebraska - Lincoln

Phyletic Coevolution between Subterranean Rodents of the Genus Ctenomys (Rodentia: Hystricognathi) and Nematodes of the Genus Paraspidodera (Heterakoidea: Aspidoderidae) in the Neotropics: Temporal and Evolutionary Implications

Scott Lyell Gardner

University of Nebraska - Lincoln, slg@unl.edu

Follow this and additional works at: https://digitalcommons.unl.edu/parasitologyfacpubs

Part of the Parasitology Commons

Gardner, Scott Lyell, "Phyletic Coevolution between Subterranean Rodents of the Genus Ctenomys (Rodentia: Hystricognathi) and Nematodes of the Genus Paraspidodera (Heterakoidea: Aspidoderidae) in the Neotropics: Temporal and Evolutionary Implications" (1991). Faculty Publications from the Harold W. Manter Laboratory of Parasitology. 64.

https://digitalcommons.unl.edu/parasitologyfacpubs/64

This Article is brought to you for free and open access by the Parasitology, Harold W. Manter Laboratory of at DigitalCommons@University of Nebraska - Lincoln. It has been accepted for inclusion in Faculty Publications from the Harold W. Manter Laboratory of Parasitology by an authorized administrator of DigitalCommons@University of Nebraska - Lincoln. 


\title{
Phyletic coevolution between subterranean rodents of the genus Ctenomys (Rodentia: Hystricognathi) and nematodes of the genus Paraspidodera (Heterakoidea: Aspidoderidae) in the Neotropics: temporal and evolutionary implications
}

\author{
SCOTT LYELL GARDNER*
}

Museum of Southwestern Biology, Department of Biology, The University of New Mexico, Albuquerque, New Mexico 87131

Received May 1990, accepted for publication October 1990

\begin{abstract}
Coevolution was studied in six species of rodents of the genus Ctenomys and their parasitic nematodes of the genus Paraspidodera, collected in Bolivia. Representatives of the families Octodontidae and Caviidae were used as outgroups for the mammals, and nematodes from caviids were used as outgroups of the nematodes from ctenomyids. For the nematodes, quantitative and qualitative morphological characteristics of both males and females and electrophoretic characters of both sexes were used to generate phylogenetic hypotheses of evolutionary relationships of the O'TLs occurring in hosts of different species. Concordance estimates of cladograms generated from biochemical-genetic and morphological data of the nematodes show a percentage incongruence (Mickevich-Farris Incongruence Statistic or $I_{\mathrm{MIF}}$ ) of $8.23 \%$ in the character sets. Parsimony mapping, testing concordance of topologies between the trees derived from both analysis of both morphological and biochemical-genetic data indicates an overall agreement of $82.3^{\circ}{ }_{0}$. Comparisons of topologies of the host and parasite cladograms, as measured with parsimony mapping, showed $70.8 \%$ concordance, indicating substantially more cospeciation than host-switching in the Ctenomys-Paraspidodera host-parasite system. Nematodes of the genus Paraspidodera appear to have invaded the Ctenomys lineage from an origin in caviids sometime before the ctenomyids began to diversify in early Pleistocene time.
\end{abstract}

KEY WORDS: - Rodentia - Bolivia - neotropics - coevolution - Nematoda - Ctenomys Paraspidodera - numerical phylogenetic analysis - allozyme electrophoresis - parsimony mapping.

\section{CONTENTS}

Introduction

Host taxa-history and systematics

Parasite taxa-history and systematics .

Puestions and hypotheses of phyletic coer

Materials and methods

Hosts - methods of study

Parasites- methods of study

Phylogenetic analysis

Hosts . 


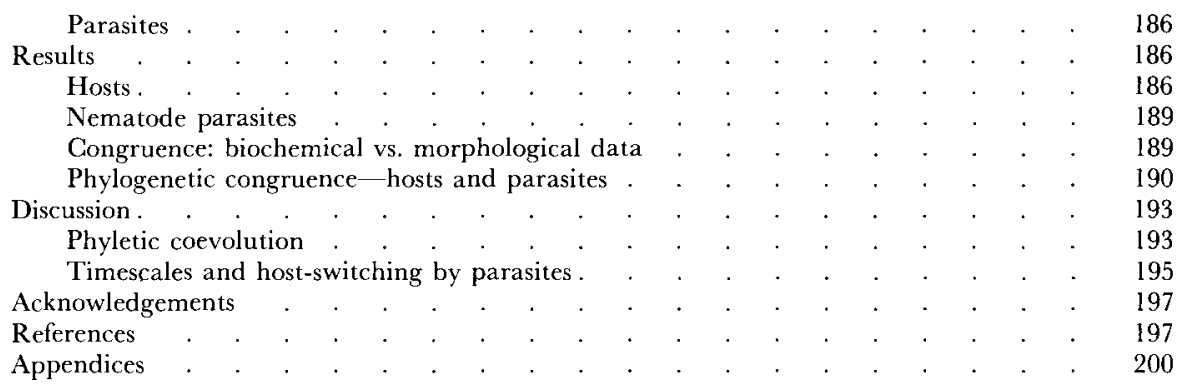

\section{INTRODUC'TION}

The topics of coevolution and historical ecology have recently been given considerable attention by workers striving to understand patterns of geographic distributions, phylogenetic relationships and ecologic associations of free-living organisms and their parasites (Brooks, 1979; Cressey, Collette \& Russo, 1983; Mitter \& Brooks, 1983; Slaughter \& Ubelaker, 1984; Kim, 1985; Humphries, Cox \& Neilsen, 1986; Brooks, 1988; Brooks \& Bandoni, 1988; Klassen \& Beverley-Burton, 1988; Brooks \& O'Grady, 1989). Brooks (1979, 1985) summarized the information concerning the historical development of the modern view of coevolution of hosts and their parasites and recently (Brooks, 1988) presented a summary and synthesis of information concerning comparison of host and parasite phylogenies.

Brooks $(1979,1981)$ used phylogenetic methods to examine patterns resulting from processes of coevolutionary phylesis, and demonstrated that these processes actually consist of two distinct categories: (1) coaccommodation, the process of anagenetic evolution (reciprocal evolutionary interactions) of the host and its parasites with no host-parasite cladogenesis implied, also termed 'ecological associations'; and (2) cospeciation, the simultaneous cladogenesis of the hosts and parasites, also representing association by descent. For example, resourcetracking (cf. Kethley \& Johnston, 1975) and host-switching are examples of coaccommodation, because host-parasite cladogenesis is not simultaneous and not linked. Cospeciation of hosts and parasites may often be simultaneous or linked, and speciation in each lineage may be caused by the same proximate factors (Brooks, 1979, 1988). The phyletic approach to studies of coevolution depends upon tests of hypotheses of congruence or concordance between phylogenetic trees developed for different taxa of closely interacting organisms (symbionts).

This paper presents the results of tests of hypotheses of host-parasite phyletic coevolutionary associations of South American hystricognath rodents (Rodentia: Hystricognathi Tullberg, 1899) of four families (Octodontidae, Caviidae, Cuniculidae and Ctenomyidae) and nematodes of the genus Paraspidodera. Travassos, 1914.

\section{Host taxa-history and systematics}

Rodents with the hystricognathous condition are known as fossils from sedimentary deposits of Deseadan Oligocene age (c.38 million years old) in Patagonia (Wood \& Patterson, 1959; Woods, 1982; Marshall, 1988). The 
hystricognathous jaw is a synapomorphy that unites all caviomorph rodents in the Neotropics into a single clade (Woods, 1982); however, Sarich \& Cronin (1981) advanced the idea of multiple invasions of hystricognath rodents into the Neotropics.

Representatives of the hystricognath rodents probably arrived in South America via waif or sweepstakes dispersal from Africa (Lavocat, 1974). This argument is strengthened by the following: the presence of closely related taxa of heligmosome nematodes in hystricognath rodents in both Africa and South America (Durette-Desset, 1971) and presence of nematodes of the genus Welcomia Sambon, 1907 in these same rodents (Hugot, 1988) indicate an African origin of hystricognath rodents, with subsequent migration to South America. After the arrival of these rodents the continent of South America was a virtual island for about 32 million years during which the hystricognath rodents underwent a period of intense adaptive diversification (Simpson, 1980; Marshall, 1988). At the present time, these rodents are represented by species included in 14 widely divergent families distributed throughout the Neotropics (Simpson, 1980; Woods, 1982). Phylogenetic relationships of hystricognath rodents in the Neotropics are poorly known, although previous systematic arrangements, at least at the level of the superfamily (Patterson \& Pascual, 1972; Sarich \& Cronin, 1981; Woods, 1982) are supported by data from protein electrophoresis (Fig. 1) (Woods, 1982). Although a robust phylogenetic hypothesis based on either morphology or molecular methods which includes representative species of all families of neotropical hystricognath rodents has not yet been published, the view that the Octodontidae (with six genera) and the Ctenomyidae (with a single genus) are sister taxa is supported by existing morphological evidence (Reig \& Spotorno, 1972; Simpson, 1980; Reig, 1986).

Rodents of the genus Ctenomys de Blainville (Hystricognathi: Ctenomyidae) first appeared in the fossil record in Argentina in late Pliocene to early Pleistocene time from 2.5 to 1.5 million years ago (mya) (Reig \& Kiblisky, 1969; Reig, 1986). These rodents are endemic to the Neotropical Region, with no known fossil record from other biogeographic regions (Simpson, 1980). Ctenomyids occupy a subterranean ecotope and exhibit morphological characteristics similar to those of other burrowing rodents such as the geomyids of the Nearctic region (Nevo, 1979; Contreras, Torres-Mura \& Yañez, 1987). Ctenomyids have rather disjunct distributions over geographic space and generally occupy habitats with friable soils from a northern limit (in) southern Peru south through Brazil, Bolivia, Chile, Paraguay, Uruguay and Argentina, to the southern tip of the continent (Mares \& Ojeda, 1982; Reig, 1986; Contreras et al., 1987). At the present time, 33 species are recognized in the genus Ctenomys (see Mares \& Woods, 1982; Mares \& Ojeda, 1982) but this number is probably a conservatively low estimate based on new data from cytogenetics (Anderson, Yates \& Cook, 1987).

\section{Parasite taxa-history and systematics}

The nematodes considered in this study are restricted to a single superfamily, the Heterakoidea of the order Ascaridida (after Chabaud, 1974). Nematodes of this superfamily are considered to represent three well-defined families: the Heterakidae Railliet \& Henry, 1912 with ten genera and a cosmopolitan 


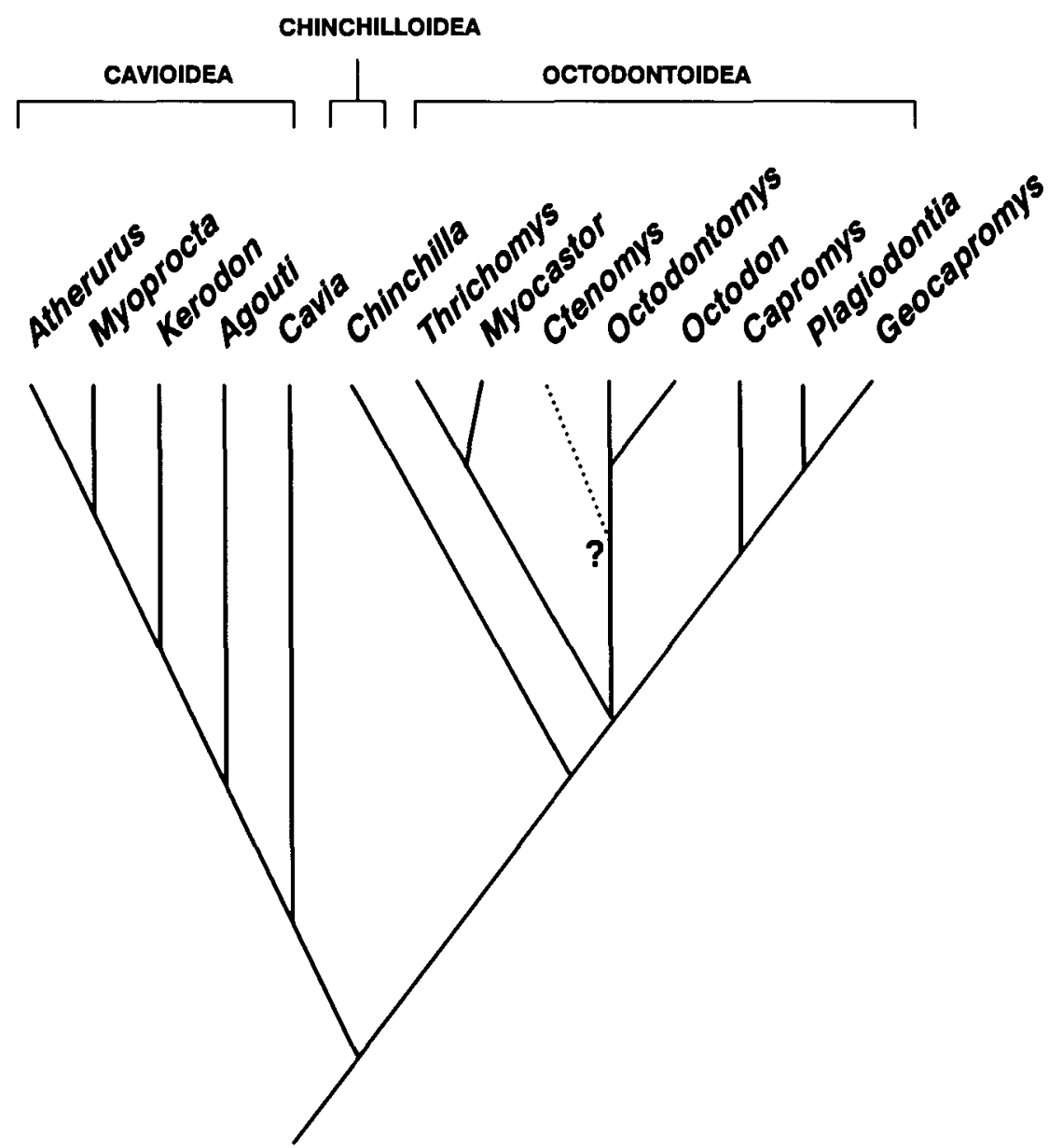

Figure 1. Cladogram depicting the evolutionary relationships among selected genera of neotropical and African hystricognath rodents. The placement of rodents of the genus Citenomys is uncertain because individuals of this genus were not included in the study (from Woods, 1982).

distribution; the Ascaridiidae Travassos, 1919 with a cosmopolitan distribution; and the Aspidoderidae Skriabin \& Schikhobalova, 1947.

Nematodes of the family Aspidoderidae are currently referred to four genera, Aspidodera Railliet \& Henry, 1912, Ansiruptodera Skriabin \& Schikhobalova, 1947, Lauroia Proenca, 1938, and Paraspidodera Travassos, 1914. These nematodes are parasitic in xenarthrans, marsupials and hystricognath rodents only in the Neotropics (Skriabin, 1951; Chabaud, 1978).

The present study primarily concerns nematodes of the genus Paraspidodera (Figs 2, 3). These worms are monoxenous (Osche, 1956), and occur in the caecum and colon of mammals representing four genera of neotropical hystricognath rodents including Cuniculus L., Cavia Pallas, Kerodon Cuvier and Ctenomys (see Lent \& de Freitas, 1939; Chabaud, 1978; Vicente, Gomes \& Filho, 1982; Ribeiro et al., 1985). Three species of Paraspidodera are currently recognized and two have been reported to occur in rodents of the genus Clenomys (see Skriabin, 1951; Chabaud, 1978). Paraspidodera uncinata (Rudolphi, 1819), first 

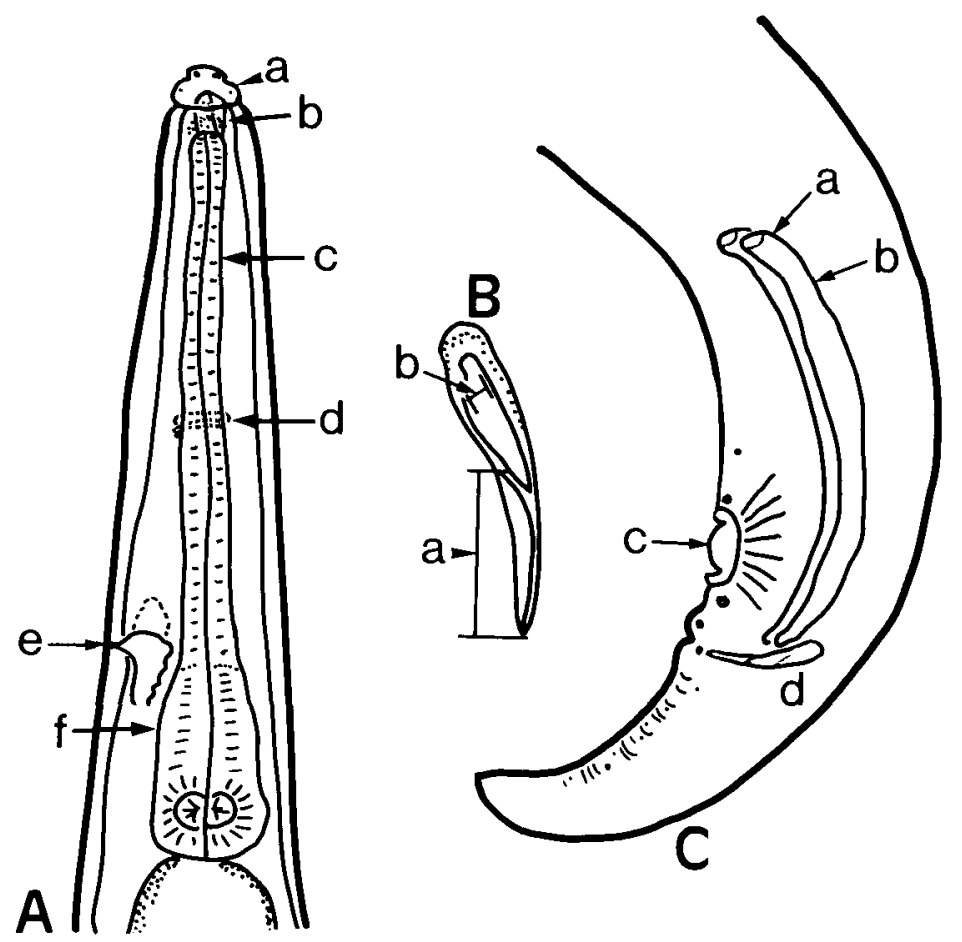

Figure 2. Line drawings of morphological characteristics of nematodes of the genus Paraspidodera. Structures of Paraspidodera that were used in the phylogenetic analysis are labelled as follows: A, Anterior end; a, anterior end showing well developed lips; b, stoma; c, oesophagus, anterior end; d, nerve ring; e, excretory pore; $f$, oesophageal bulb. B, Gubernaculum, expanded view: a, blade; b, inside diameter. C, Posterior end of male Paraspidodera: a, spicule, proximal end; b, spicule neck; c, pre-anal sucker; d, gubernaculum.

known from Cavia aperea Erxleben and Cuniculus paca L. in South America, was reported to have been collected from Ctenomys opimus Wagner in Oruro, Bolivia (Lent \& De Freitas, 1939). Paraspidodera americana Khalil \& Vogelsang, 1931, and P. uruguaya Khalil \& Vogelsang, 1931 were described from Ctenomys magellanicus Bennett and Cavia aperea L., respectively (Khalil \& Vogelsang, 193la,b; Lent \& De Freitas, 1939; Chabaud, 1978).

During a survey of the mammalian fauna of Bolivia (1984-1988) nematodes of the genus Paraspidodera were obtained from several populations representing six recognized species and two subspecies of Ctenomys. These nematodes are specific for the different species of Ctenomys from which they were collected, and most species can be differentiated using standard morphological criteria. For the purposes of this paper, and except for two sub-OTUs (OTU = operational taxonomic unit) from $C$. opimus, nematodes occurring in a single species of host were considered as separate operational taxonomic units (OTUs). Descriptions of several new species of these nematodes from Ctenomys and other rodents from Bolivia are being prepared.

The minimum requirements and properties for a successful study of this type include the following: (1) relatively host-specific: nematodes of the genus Paraspidodera are relatively host-specific and occur only in four genera of hystricognath rodents; (2) high density per host: Paraspidodera occur in high 

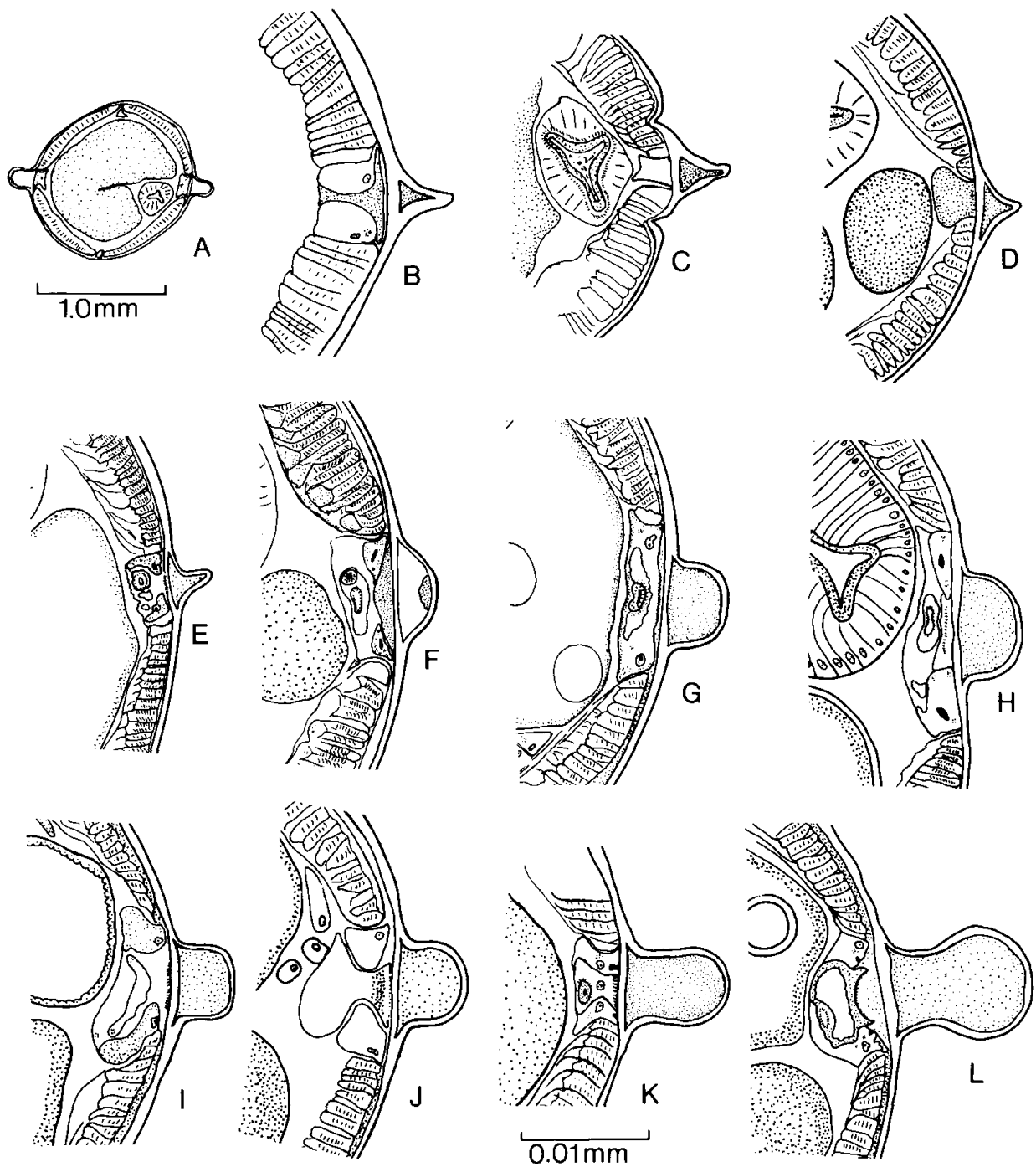

Figure 3. Line drawings of cross sections of nematodes of the genus Paraspidodera, illustrating the shape and relative height of the lateral alae. Nematodes of the genus Paraspidodera are bilaterally symmetrical with respect to the lateral alae, illustrated in $A$; thus only one side of each section is shown. The actual size of $\mathrm{A}$ is indicated by the $1.0 \mathrm{~mm}$ measurement bar; all other sections are drawn to the scale represented by the $0.01 \mathrm{~mm}$ measurement bar beneath $\mathrm{K}$. Key for drawings gives the collection number and the genus and/or species of host, followed by general collection locality; see Appendix 1 for a complete list of specimens examined and collection localities. M, Male; F, female. A, NK 14557, Ctenomys opimus, Rio Barros, M. B, NHMP3344 Cavia porcellus, Venezuela, M. C, USNM42585 Cavia, Loc. ?, F. D, NK 11573 Ctenomys conoveri, Chuquisaca, M. E, NK 14652 Ctenomys lewisi, Iscayachi, M. F, NK15199 Ctenomys steinbachi, Santa Cruz, F. G, NK 14622 Ctenomys frater, R. Tambo, F. H, NK13031 Ctenomys boliviensis goodfellowi, La Laguna, F. I, NK 15064 Clenomys boliviensis boliviensis, Santa Cruz, F. J, NK14557 Clenomys opimus, Rio Barros, M. K, NK14766 Citenomys opimus Huancaroma, $\mathbf{F}$.

prevalence and relatively great numerical density in most populations of Ctenomys that were sampled, thus it was relatively easy to obtain adequate samples of the nematodes; (3) morphological and ecological variability or numerous species of host group; species of Ctenomys in Bolivia have a wide distribution among 


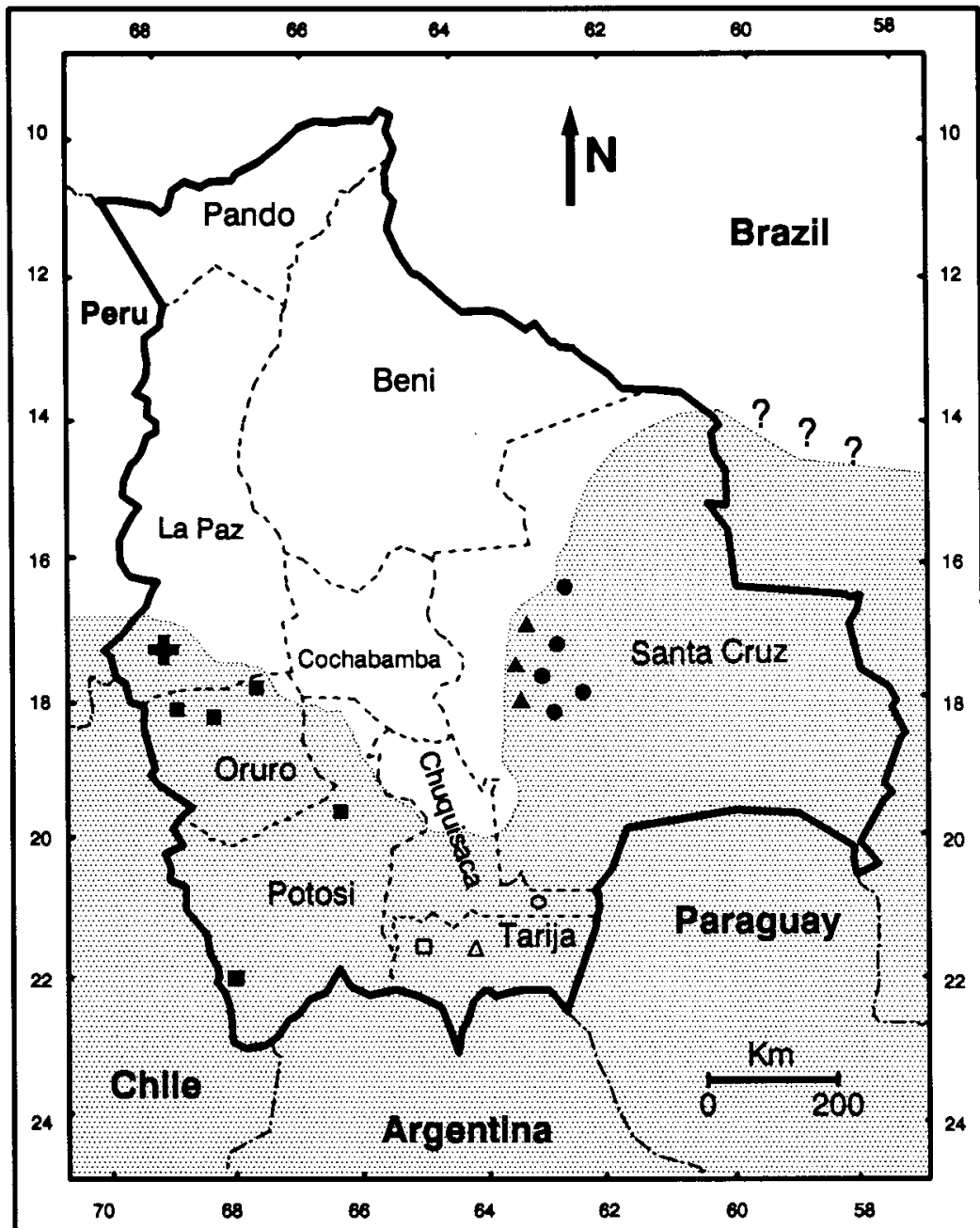

$$
\begin{array}{ll}
\bullet=\text { Ctenomys boliviensis } & \square=C . \text { lewisi } \\
0=C \text {. conoveri } & \square=C . \text { opimus } \\
\Delta=\text { C. frater } & \Delta=C \text {. steinbachi } \\
+=C . \text { leucodon } &
\end{array}
$$

Figure 4. Map of Bolivia with major collecting localities of all species of Ctenomys indicated. Shaded areas represents approximate distribution of Clenomys.

extremely diverse habitats (Fig. 4) with a great deal of interspecific variability in morphologic and karyotypic features (Anderson, Yates \& Cook, 1987; Cook, Anderson \& Yates, in press).

\section{Questions and hypotheses of phyletic coevolution}

One primary question and some correlated hypotheses are addressed. Does strict cospeciation operate in this system or are the parasites randomly associated with their mammalian hosts? The following hypotheses, developed in the context 
of phyletic coevolution, can be applied to any host-parasite assemblage. (1) Null hypothesis. Hosts are randomly colonized. In this case, no pattern of concordance between phylogenies of hosts and parasites is evident. Parasites colonize after the host taxon has appeared via transfer from existing hostparasite associations. This represents host-switching, or the "phénomène de capture" (Chabaud, 1957). Failure to falsify the null hypothesis leads to (2) Alternative hypothesis. Some pattern of cospeciation between hosts and parasites is evident. This is indicated by congruence of phylogenetic hypotheses constructed for both hosts and parasites. Additional failures to falsify the alternative hypothesis will lead to at least two additional questions. First, are cladograms of hosts and parasites completely congruent? If so, this would represent host-parasite cospeciation without host-switching occurring. Second, are cladograms of hosts and parasites partially congruent? If so, this pattern would indicate that both cospeciation and transfer between hosts has occurred.

\section{MATERIALS AND METHODS}

\section{Hosts - methods of study}

Mammals were collected, processed and necropsied following the general procedures given by Gardner (1984) and Anderson et al. (1987). Definitions of OTUs and numbers of specimens studied are given in Table 1. Collection localities and museum numbers of each OTU are given in Appendix 1.

Quantitative characters. For the morphological analysis of the rodents, I used measurements of characters described by Anderson et al. (1987). Because sample sizes for most individual localities were small, morphological data from specimens of a species obtained from different localities were combined to form OTUs. Standard measurements of external characters were used as well as measurements from skulls (Fig. 5, Table 2) taken with digital calipers to the nearest $0.1 \mathrm{~mm}$ (see also Anderson et al., 1987). Characters and character-state information for all quantitative mensural characters of the mammals are given in Appendix 2 and the matrix of coded character-states is given in Table 3.

Qualitative characters. Qualitative data used for phylogenetic analysis (e.g. shape of characters, see Appendix 2) were useful in defining each taxon because these characters exhibited less intraspecific variation relative to the amount of interspecific variation that was observed. Qualitative characteristics were identified from examination of skulls and study skins. To eliminate the effect of sexual dimorphism on the analysis, only characters of adult females were used (Appendix 2). Characters of the chromosomes (diploid and fundamental numbers) were coded as indicated in Appendix 2. Although some evidence indicates that standard karyotypes of Ctenomys may yield low resolution in terms of phylogenetic relationships (Cook et al., in press) no information concerning chromosome band patterns is yet available concerning phylogenetic relationships among these rodents.

\section{Parasites-methods of study}

Nematodes recovered alive were killed in glacial acetic acid, fixed in 10\% aqueous formalin, and stored in this solution or in $70 \%$ ethanol (ETOH). 


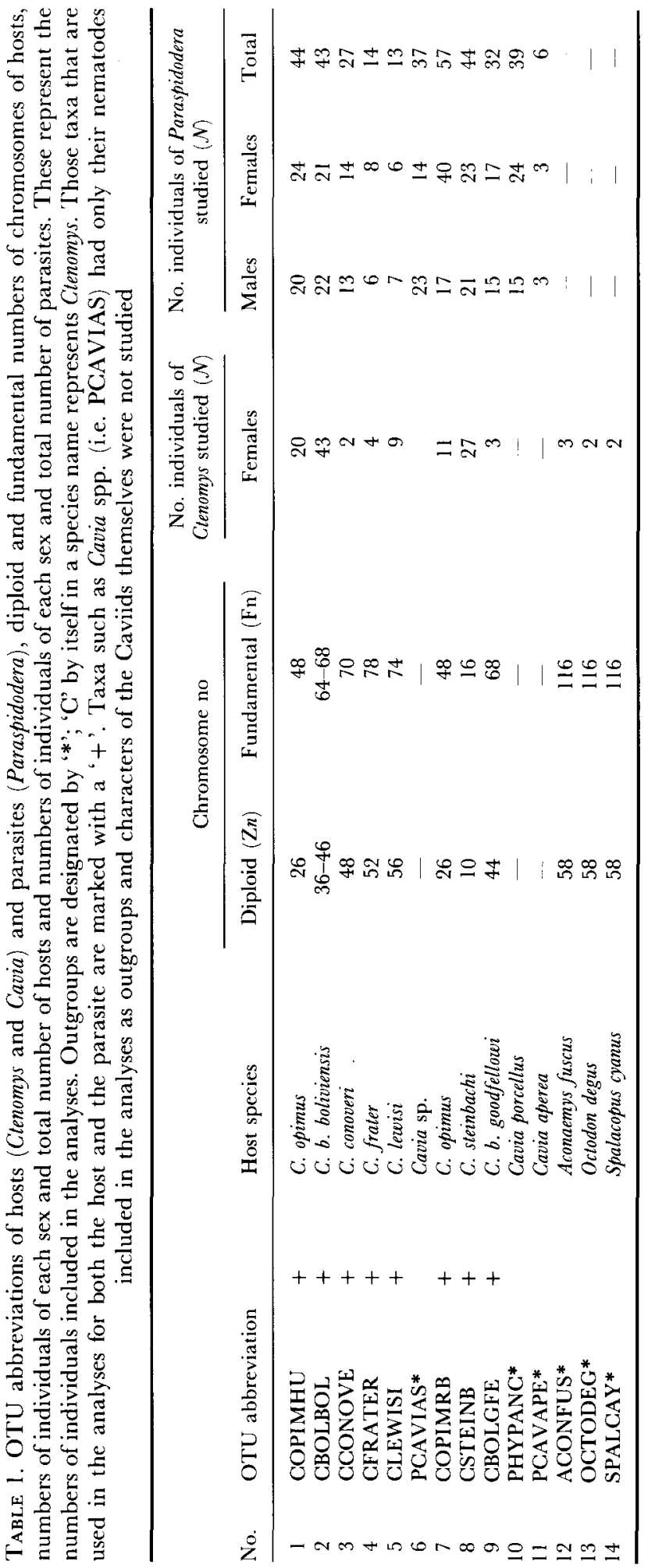



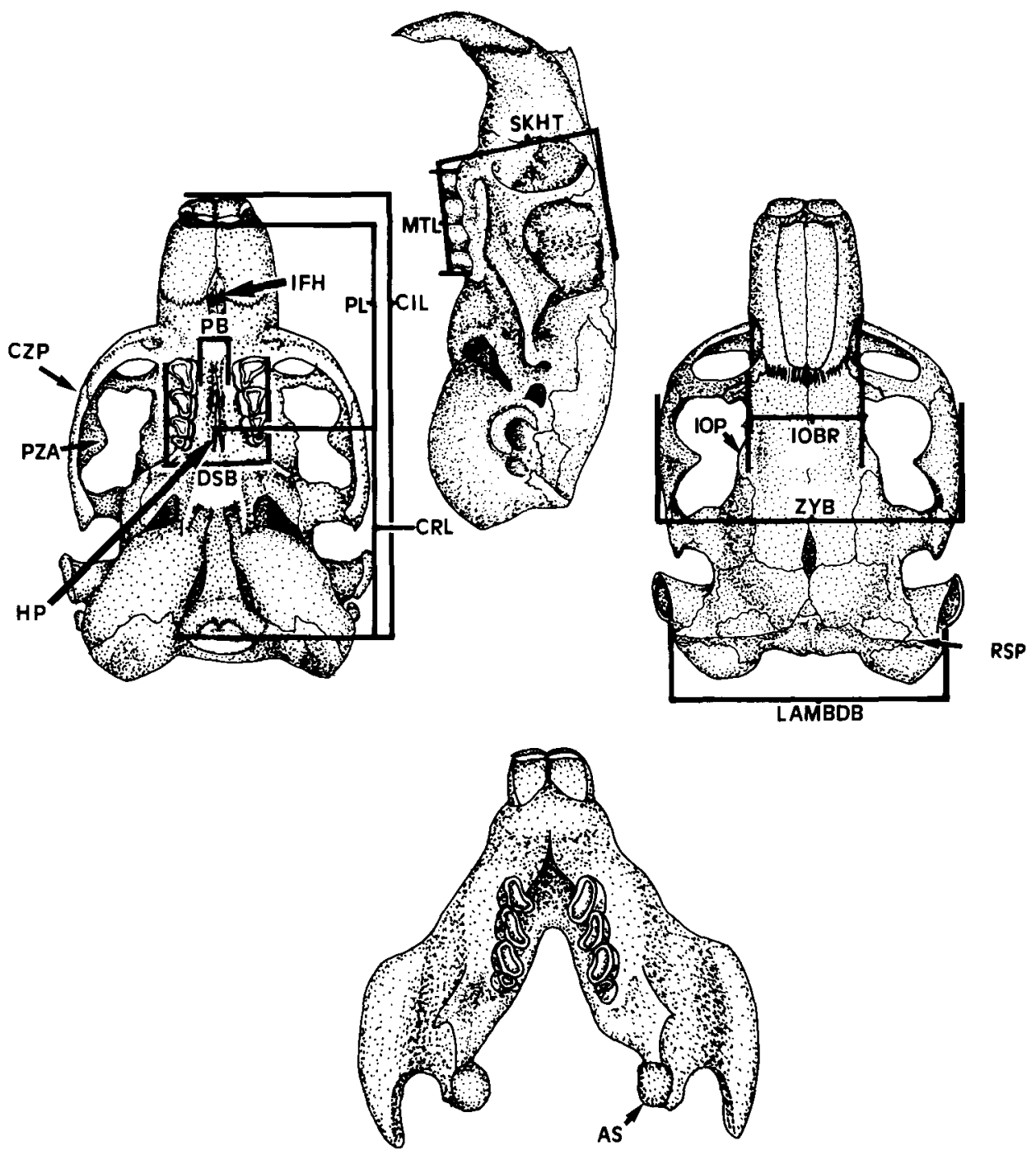

Figure 5. Generalized skull of Ctenomys showing characters used in the phylogenetic analysis. Label definitions follow Table 2.

Worms were prepared for light microscopy following the procedure outlined by Gardner (1984).

Quantitative measurements were made using a Zeiss Universal microscope equipped with an ocular micrometer or a video digitizer. Because of possible distortion of the cuticle due to fixation, measurements of widths of the body were omitted from the analysis (Fagerholm, 1982). Morphological characters of the nematodes (Figs 2,3) are listed in Table 4. Only individuals determined to be adults on the basis of body size and relative development of the reproductive organs were studied. The degree of development of the lateral alae was determined by cutting cross-sections at midbody and mounting them on a slide in glycerol and lactic acid. The degree of development of the lateral alae in these aspidoderid nematodes proved to be a character that was consistent within but 
TABLE 2. List of qualitative and quantitative variables used in the analysis of phylogenetic relationships of rodents of the genus Ctenomys from Bolivia. The first 15 characters are standard mensural external and cranial characters. The following eight characters represent qualitative characters determined from study of the skulls and lower mandibles; these characters were used for phylogenetic analysis and were coded as shown in Appendix 2. See also Fig. 5 and Anderson et al.

(1987) for definitions of these characters

\begin{tabular}{rll}
\hline Code & Character abbreviation & Character definition \\
\hline 1 & LAMBDB & Lambdoidal breadth \\
2 & TAILL & Tail length \\
3 & EARL & Ear length \\
4 & IOBR & Interorbital breadth \\
5 & ZYB & Zygomatic breadth \\
6 & PL & Palatal length \\
7 & WEIGHT & Body weight \\
8 & SKHT & Skull height \\
9 & DSB & Dental span breadth \\
10 & PB & Palatal breadth \\
11 & MTL & Molar tooth row length \\
12 & CRL & Condylo-root length \\
13 & HFL & Hind foot length \\
14 & CIL & Condylobasalar length \\
15 & TOTL & Total length of body \\
16 & IOP & Interorbital process \\
17 & PZA & Process of zygomatic arch \\
18 & CZP & Curvature of zygomatic process \\
19 & AS & Articulation surface- coronoid process \\
20 & RTI & Roots of top incisors \\
21 & HP & Hole in presphenoid bone \\
22 & IFH & Incisive foramen- holes \\
23 & RSP & Ridge and suture of parietal \\
\hline
\end{tabular}

varied among OTUs, thus proving to be useful in both taxonomic separation of OTUs and in coding for cladistic analysis. Appendix 3 contains information on coding that was used for all characters of nematodes included in the analysis.

Scanning electron microscopy was used to examine qualitative characters of the cuticle (Wertheim \& Chabaud, 1977) and degree of development of the cephalic lips (Fig. 2a).

Electrophoresis. Nematodes were frozen in liquid nitrogen in the field and stored at $-70^{\circ} \mathrm{C}$ until used for electrophoresis. During homogenization (described below), the temperatures of all specimens and solutions were maintained near $4^{\circ} \mathrm{C}$. Prior to analysis using standard starch gel protein electrophoresis, individual nematodes were separated, identified to genus, thawed, and rinsed in tissue grinding solution $(1.21 \mathrm{~g}$ Tris Base, $0.34 \mathrm{~g}$ EDTA disodium salt, $4 \mathrm{ml}$ $1.0 \% \mathrm{NADP}, 11 \mathrm{DHOH} \mathrm{pH} 7.0$ ), and then homogenized completely in $20 \mu \mathrm{l}$ of grinding solution. To ensure that the enzymes that were studied originated from the parasites and not from the host, liver samples and caecal contents from an individual host were included on several trial electrophoretic runs of nematodes. Comparisons of the location and nature of the proteins visualized by biochemical staining from both rodents and nematodes revealed no detectable contamination of enzymes from the nematodes with protein from the host.

Methods of horizontal starch-gel electrophoresis and biochemical staining were modified from those described by Leslie et al. (1982) and Richardson, Baverstock \& Adams (1986). Gel types, electrical parameters and procedures for 


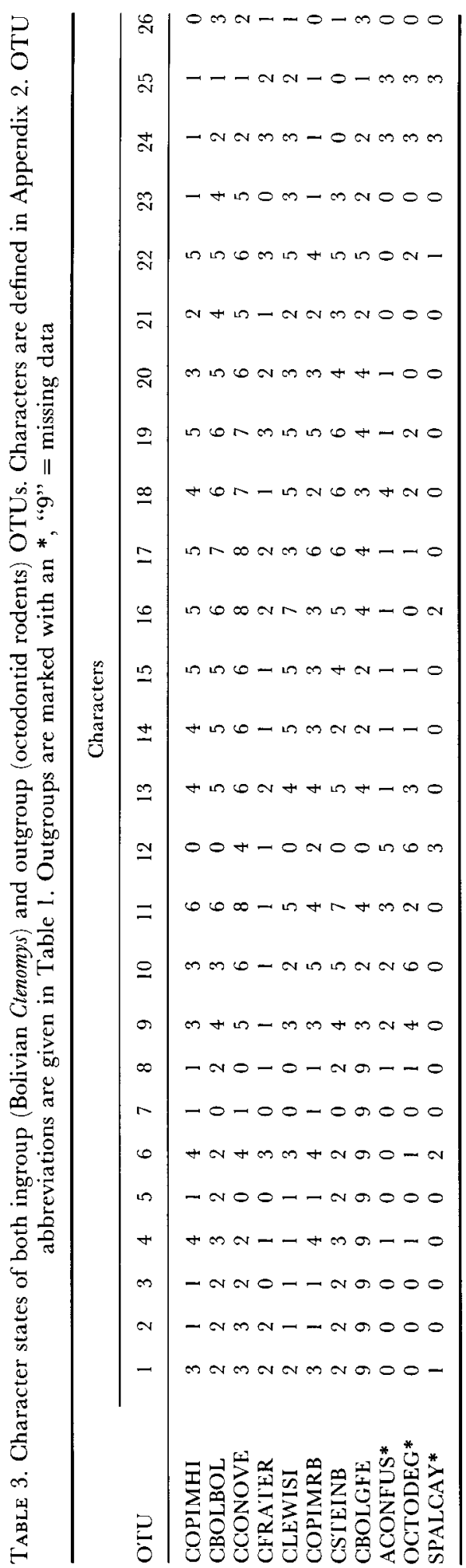


TABLE 4. List of quantitative, qualitative and allozyme characters for the nematodes used in Table 7, Appendix 2 and Fig. 10. The numerical code is given first followed by the character abbreviation and the character definition

\begin{tabular}{llll}
\hline $\begin{array}{l}\text { Code } \\
\text { no. }\end{array}$ & $\begin{array}{l}\text { Character } \\
\text { definition }\end{array}$ & $\begin{array}{l}\text { Code } \\
\text { no. }\end{array}$ & $\begin{array}{l}\text { Character } \\
\text { definition }\end{array}$ \\
\hline
\end{tabular}

1 Length of oesophagus

2 Excretory pore to anterior end

3 Left spicule length

4 Right spicule length

5 Nerve ring to anterior end

6 Width of oesophagus bulb

7 Length of oesophagus bulb

8 Oesoph. bulb width (min.)

9 Head width males

10 Length of head males

11 Tail length males

12 Left spicule width (max.)

13 Left spicule width ( $\min$.)

14 Left spic. width proximal end

15 Left spic. proximal length

16 Right spic. width (max.)

17 Right spicule width (min.)

18 Right spic. w. proximal end

19 Right spicule 1. proximal end

20 Gubernaculum length

21 Gubernaculum maximum width

22 Gubernaculum blade max. width

23 Gubernaculum inside diameter

24 Gubernaculum blade length

25 Lateral alae shape

26 Lateral alae height

27 Dev. of excretory ducts
28 Larvae present or absent

29 Interdigitization of lips

30 Total length of female

31 L. of oesophagus of female

$32 \mathrm{~W}$. of oesophageal bulb female

$33 \mathrm{~L}$. of oesophageal bulb female

$34 \mathrm{~W}$. of oesoph. bulb (min.) female

35 Nerve ring to head end female

36 Excretory pore to head female

37 Stoma length female

38 Length of head females

39 Length of tail female

40 Width of anus female

41 Length of egg

42 Width of egg

43 Glycyl-leucyl-leucine

44 Creatine kinase

45 Phosphoglucomutase-2

46 Phosphoglucomutase-1

47 Glucose phosphate isomerase-1

48 Glucose phosphate isomerase-2

49 Glucose phosphate isomerase-3

50 Glutamate dehydrogenase

51 Leucine alanine

52 Leucyl-glycyl-glycine- 1

53 Leucyl-glycyl-glycine-2

54 Malate dehydrogenase-1

55 Malate dehydrogenase-2

staining are listed in Table 5. Formulae for the buffer systems can be found in Richardson et al. (1986), and Leslie et al. (1982). Ten staining systems (13 presumptive loci) were consistently resolved. Designation of alleles or allozymes for each presumptive locus or isozyme followed that of Yates \& Greenbaum (1982). Representative of all populations were run side by side to directly compare relative mobilities of alleles. Table 6 contains designations of 13 loci, OTUs, number of alleles, allele frequencies, character state for each locus, and numbers of individuals studied for all OTUs of nematodes considered in this study.

A single method of coding data derived from allozyme electrophoresis for use in numerical phylogenetic analysis has not been accepted (Mickevich \& Mitter, 1983; Buth, 1984; Swofford \& Berlocher, 1987; Dowling \& Brown, 1989). However, two fundamentally different methods of coding data for numerical phylogenetic analysis have been used in the recent literature; the phenetic alleleas-character method (Dowling \& Brown, 1989) and the phylogenetic locus-ascharacter method (see Buth, 1984; Dowling \& Brown, 1989).

The phylogenetic method of coding data derived from electrophoresis assumes the locus as the fundamental unit upon which evolution operates, i.e. locus-ascharacter (Mickevich \& Mitter, 1981; Buth, 1984). Because the goals of the present paper were to determine the phylogenetic relationships among groups of 
TABLE 5. Electrode and gel buffer solutions and biochemical parameters used to resolve 13 enzyme loci. Enzymes are listed with Enzyme Commission (E.C.) numbers. Acid citrate = (A.C.), Gel pH is given first followed by Tray pH. (CK, Creatine kinase, GDH, Glutamate dehydrogenase, GPI, Glucose phosphate isomerase, $\mathrm{MDH}$, Malate dehydrogenase; PGM, Phosphoglucomutase; PEP-GLL substrate, Glycyl-leucyl-leucine; PEP-la substrate, Leucyl-alanine; PEP-LGG substrate, Leucyl-glycyl-glycine)

\begin{tabular}{llccccc}
\hline Enzyme & E.C. number & $\begin{array}{c}\text { Number of } \\
\text { loci }\end{array}$ & $\begin{array}{c}\text { Gel and } \\
\text { electrode buffer }\end{array}$ & $\begin{array}{c}\text { Run time } \\
(\mathbf{h})\end{array}$ & $\begin{array}{c}\text { Power } \\
(\mathbf{m A})\end{array}$ & $\begin{array}{c}\text { Movement } \\
(+ \text { or }-)\end{array}$ \\
\hline CK & 2.7 .3 .2 & 1 & A.C., $7.0,7.0$ & 2.5 & 75 & - \\
GDH & 1.4 .1 .3 & 1 & A.C., $7.0,7.0$ & 2.5 & 75 & + \\
GPI & 5.3 .1 .9 & 3 & A.C., $7.0,7.0$ & 2.5 & 75 & $+1-$ \\
& & & A.C., $6.4,7.4$ & 2.5 & 75 & $+1-$ \\
MDH & 1.1 .1 .37 & 2 & A.C., $7.0,7.0$ & 2.5 & 75 & - \\
& & & A.C., $6.4,7.4$ & 2.5 & 75 & + \\
PEP-GLL & 3.4 .11 or 3.4 .12 & 1 & A.C., $7.0,7.0$ & 2.5 & 75 & $+1-$ \\
& & 1 & A.C., $6.4,7.4$ & 2.5 & 75 & - \\
PEP-LA & 3.4 .11 or 3.4 .12 & 2 & A.C., $7.0,7.0$ & 2.5 & 75 & $+1-$ \\
PEG-LGG & 3.4 .11 or 3.4 .12 & A.C., $7.0,7.0$ & 2.5 & 75 & $+1-$ \\
PGM & 2.7 .5 .1 & 2 & A.C., $7.0,7.0$ & 2.5 & 75 & $+1-$ \\
\hline
\end{tabular}

nematodes and the coevolutionary relationships of the hosts and parasites, a locus-as-character method of coding was utilized.

In the present case, considering the locus as the character, coding was performed by starting with the outgroup (see Fig. 6), and each new most common allele that occurred in a frequency of $>50 \%$ that was encountered in the matrix was coded with a successive number (qualitative successive integer coding). If the alleles occurred in a 50-50 tie, the data for this OTU were denoted as missing. Figure 6 shows a graphical presentation of the method of coding, where the OTUs are arbitrarily placed in a sequence. The character-state data-matrix (Table 7) contains 55 characters representing qualitative, quantitative and electrophoretic data for both male and female nematodes.

Rodents representing several species of Ctenomys were collected from remote areas in Bolivia, and as it was not possible to obtain large sample sizes of nematodes from these, the minimum sample size for electrophoresis was two individuals per OTU. For data derived from starch-gel allozyme electrophoresis, estimations of phylogenetic relationships using cladistic methods have been shown to work well with small sample sizes (Gorman \& Renzi, 1979; Richardson et al., 1986), although phenetic methods of determining ancestor-descendant relationships (based on distances and clustering techniques) may be subject to instability due to size of sample (Archie, Simon \& Martin, 1989; Sage et al., 1986)

\begin{tabular}{lccccccc} 
TAXON (OTU): & OUTG & 1 & 2 & 3 & 4 & 5 & 6 \\
\hline Prevalent Allele: & AA BB & BB CC AA & CC & AC \\
Integer Code: & (0) & $(1)$ & $(1)$ & $(2)$ & $(0)$ & $(2)$ & $(?)$ \\
& start> & & & & & &
\end{tabular}

Figure 6. Method of coding electrophoretic biochemical-genetic data using qualitative successive integer coding, here the '?' denotes a missing data code. See Materials and methods for explanation. 
TABLE 6. Allele frequencies and character states for all loci studied in OTUs $1-10$ representing species of Paraspidodera, Heterakis and Ascaridia. Names of OTUs 1-8 follow same format as Table 1, for O'TUs 9 and 10, see Appendix 1. 1, POPIMHU; 2, PBOLBOL; 3, PCONOVE; 4, PSTEINB, 5, PBOLGFE; 6, PFRATER; 7, PLEWISI; 8, POPIMRB; 9, ASCARID; 10, HETERAK; 9 , missing data

\begin{tabular}{|c|c|c|c|c|c|c|c|c|c|c|c|}
\hline \multicolumn{12}{|c|}{ OTU designation } \\
\hline Locus & elc & 1 & 2 & 3 & 4 & 5 & 6 & 7 & 8 & 9 & 10 \\
\hline \multirow[t]{3}{*}{ Sample size } & & 2 & 3 & 3 & 3 & 2 & 3 & 3 & 4 & 1 & 4 \\
\hline & A & 0.50 & 0.00 & 0.00 & 0.00 & 0.00 & 0.17 & 0.00 & 0.00 & 0.00 & 0.00 \\
\hline & B & 0.50 & 1.00 & 0.00 & 1.00 & 1.00 & 0.83 & 1.00 & 1.00 & 0.00 & 0.00 \\
\hline \multirow[t]{4}{*}{ Pep-Gll } & $\mathrm{C}$ & 0.00 & 0.00 & 0.33 & 0.00 & 0.00 & 0.00 & 0.00 & 0.00 & 0.00 & 0.50 \\
\hline & $\mathrm{D}$ & 0.00 & 0.00 & 0.17 & 0.00 & 0.00 & 0.00 & 0.00 & 0.00 & 0.00 & 0.50 \\
\hline & $\mathbf{E}$ & 0.00 & 0.00 & 0.50 & 0.00 & 0.00 & 0.00 & 0.00 & 0.00 & 0.00 & 0.00 \\
\hline & $\mathbf{F}$ & 0.00 & 0.00 & 0.00 & 0.00 & 0.00 & 0.00 & 0.00 & 0.00 & 1.00 & 0.00 \\
\hline Character state & & 9 & 2 & 3 & 2 & 2 & 2 & 2 & 2 & 1 & 9 \\
\hline \multirow[t]{2}{*}{ Sample size } & & 2 & 3 & 3 & 3 & 2 & 3 & 3 & 4 & 1 & 3 \\
\hline & A & 0.00 & 0.00 & 0.00 & 0.00 & 0.00 & 0.00 & 0.00 & 0.00 & 1.00 & 0.00 \\
\hline \multirow[t]{2}{*}{ CK } & B & 0.00 & 0.00 & 0.00 & 0.33 & 0.50 & 0.00 & 0.00 & 0.75 & 0.00 & 1.00 \\
\hline & $\mathrm{C}$ & 1.00 & 1.00 & 1.00 & 0.67 & 0.50 & 1.00 & 1.00 & 0.25 & 0.00 & 0.00 \\
\hline Character state & & 3 & 3 & 3 & 3 & 9 & 3 & 3 & 2 & 1 & 0 \\
\hline \multirow[t]{3}{*}{ Sample size } & & 2 & 1 & 3 & 2 & 2 & 3 & 3 & 4 & 1 & 0 \\
\hline & A & 0.00 & 0.00 & 0.00 & 0.00 & 0.50 & 0.83 & 0.50 & 0.12 & 0.00 & 0.00 \\
\hline & B & 1.00 & 0.00 & 1.00 & 0.00 & 0.00 & 0.00 & 0.00 & 0.25 & 0.00 & 0.00 \\
\hline \multirow[t]{3}{*}{ PGM-1 } & $\mathrm{C}$ & 0.00 & 0.00 & 0.00 & 0.00 & 0.00 & 0.00 & 0.00 & 0.63 & 0.00 & 0.00 \\
\hline & D & 0.00 & 1.00 & 0.00 & 1.00 & 0.50 & 0.00 & 0.00 & 0.00 & 0.00 & 0.00 \\
\hline & $\mathrm{E}$ & 0.00 & 0.00 & 0.00 & 0.00 & 0.00 & 0.17 & 0.50 & 0.00 & 1.00 & 0.00 \\
\hline Character state & & 4 & 3 & 4 & 3 & 9 & 2 & 9 & 1 & 0 & 9 \\
\hline \multirow[t]{3}{*}{ Sample sizc } & & 2 & 2 & 3 & 3 & 2 & 3 & 3 & 4 & 1 & 1 \\
\hline & A & 0.00 & 0.75 & 0.00 & 0.00 & 0.00 & 0.17 & 0.00 & 0.00 & 1.00 & 0.00 \\
\hline & B & 0.00 & 0.00 & 0.50 & 0.00 & 0.50 & 0.00 & 0.00 & 0.00 & 0.00 & 0.00 \\
\hline \multirow[t]{3}{*}{ PGM-2 } & $\mathrm{C}$ & 0.00 & 0.00 & 0.17 & 0.33 & 0.00 & 0.83 & 1.00 & 0.00 & 0.00 & 1.00 \\
\hline & D & 0.00 & 0.25 & 0.33 & 0.67 & 0.50 & 0.00 & 0.00 & 0.00 & 0.00 & 0.00 \\
\hline & $\mathrm{E}$ & 1.00 & 0.00 & 0.00 & 0.00 & 0.00 & 0.00 & 0.00 & 1.00 & 0.00 & 0.00 \\
\hline Character state & & 2 & 1 & 4 & 3 & 9 & 0 & 0 & 2 & 1 & 0 \\
\hline \multirow[t]{2}{*}{ Sample size } & & 2 & 3 & 3 & 3 & 2 & 3 & 3 & 5 & 1 & 0 \\
\hline & A & 0.00 & 1.00 & 1.00 & 1.00 & 1.00 & 1.00 & 1.00 & 0.00 & 0.00 & 0.00 \\
\hline \multirow[t]{2}{*}{ GPI! } & $\mathrm{B}$ & 1.00 & 0.00 & 0.00 & 0.00 & 0.00 & 0.00 & 0.00 & 1.00 & 0.00 & 0.00 \\
\hline & $\mathrm{C}$ & 0.00 & 0.00 & 0.00 & 0.00 & 0.00 & 0.00 & 0.00 & 0.00 & 1.00 & 0.00 \\
\hline Character state & & 1 & 2 & 2 & 2 & 2 & 2 & 2 & 1 & 0 & 9 \\
\hline \multirow[t]{4}{*}{ Sample size } & & 2 & 3 & 3 & 3 & 2 & 3 & 3 & 4 & 2 & 1 \\
\hline & A & 0.00 & 0.00 & 0.00 & 0.00 & 0.00 & 0.00 & 0.00 & 0.12 & 0.00 & 0.00 \\
\hline & B & 0.25 & 0.00 & 0.00 & 0.00 & 0.00 & 0.00 & 0.00 & 0.12 & 0.00 & 0.00 \\
\hline & $\mathrm{C}$ & 0.50 & 1.00 & 0.00 & 0.00 & 1.00 & 1.00 & 1.00 & 0.50 & 0.00 & 0.00 \\
\hline \multirow[t]{4}{*}{ GPI-2 } & $\mathrm{D}$ & 0.25 & 0.00 & 0.00 & 0.00 & 0.00 & 0.00 & 0.00 & 0.25 & 0.00 & 0.00 \\
\hline & $\mathrm{E}$ & 0.00 & 0.00 & 1.00 & 0.83 & 0.00 & 0.00 & 0.00 & 0.00 & 0.00 & 0.00 \\
\hline & $\mathbf{F}$ & 0.00 & 0.00 & 0.00 & 0.16 & 0.00 & 0.00 & 0.00 & 0.00 & 0.00 & 0.00 \\
\hline & G & 0.00 & 0.00 & 0.00 & 0.00 & 0.00 & 0.00 & 0.00 & 0.00 & 1.00 & 1.00 \\
\hline Character state & & 1 & 1 & 2 & 2 & 1 & 1 & 1 & 1 & 0 & 0 \\
\hline \multirow[t]{3}{*}{ Sample size } & & 2 & 3 & 3 & 3 & 2 & 3 & 3 & 4 & 2 & 1 \\
\hline & A & 0.50 & 0.00 & 0.00 & 0.00 & 0.00 & 0.00 & 0.00 & 0.37 & 0.00 & 0.00 \\
\hline & B & 0.50 & 1.00 & 0.00 & 0.00 & 1.00 & 1.00 & 1.00 & 0.62 & 0.00 & 0.00 \\
\hline \multirow[t]{3}{*}{ GPI-3 } & $\mathrm{C}$ & 0.00 & 0.00 & 1.0 & 1.00 & 0.00 & 0.00 & 0.00 & 0.00 & 0.00 & 0.00 \\
\hline & $\mathrm{D}$ & 0.00 & 0.00 & 0.00 & 0.00 & 0.00 & 0.00 & 0.00 & 0.00 & 1.00 & 0.00 \\
\hline & $\mathbf{E}$ & 0.00 & 0.00 & 0.00 & 0.00 & 0.00 & 0.00 & 0.00 & 0.00 & 0.00 & 1.00 \\
\hline Character state & & 9 & 2 & 1 & 1 & 2 & 2 & 2 & 2 & 1 & 0 \\
\hline
\end{tabular}


TABLE 6-continued

\begin{tabular}{|c|c|c|c|c|c|c|c|c|c|c|c|}
\hline \multicolumn{12}{|c|}{ OTU designation } \\
\hline Locus & Allele & 1 & 2 & 3 & 4 & 5 & 6 & 7 & 8 & 9 & 10 \\
\hline \multirow[t]{2}{*}{ Sample size } & & 1 & 2 & 3 & 3 & 2 & 3 & 3 & 4 & 2 & 3 \\
\hline & A & 0.00 & 0.00 & 0.00 & 0.00 & 0.00 & 0.00 & 0.00 & 0.00 & 1.00 & 1.00 \\
\hline \multirow[t]{2}{*}{ GDH } & B & 1.00 & 1.00 & 1.00 & 0.00 & 0.50 & 0.66 & 0.66 & 1.00 & 0.00 & 0.00 \\
\hline & $\mathrm{C}$ & 0.00 & 0.00 & 0.00 & 1.00 & 0.50 & 0.33 & 0.33 & 0.00 & 0.00 & 0.00 \\
\hline Character state & & 2 & 2 & 2 & 3 & 9 & 2 & 2 & 2 & 1 & 0 \\
\hline \multirow[t]{2}{*}{ Sample size } & & 1 & 2 & 3 & 3 & 2 & 3 & 3 & 4 & 2 & 2 \\
\hline & A & 0.50 & 0.00 & 0.00 & 0.00 & 0.00 & 0.00 & 0.00 & 0.00 & 0.00 & 0.00 \\
\hline \multirow[t]{3}{*}{ PEP-LA } & $\mathrm{B}$ & 0.50 & 1.00 & 0.00 & 1.00 & 1.00 & 1.00 & 1.00 & 1.00 & 0.00 & 1.00 \\
\hline & $\mathrm{C}$ & 0.00 & 0.00 & 1.00 & 0.00 & 0.00 & 0.00 & 0.00 & 0.00 & 0.00 & 0.00 \\
\hline & $\mathrm{D}$ & 0.00 & 0.00 & 0.00 & 0.00 & 0.00 & 0.00 & 0.00 & 0.00 & 1.00 & 0.00 \\
\hline Character state & & 9 & 0 & 2 & 0 & 0 & 0 & 0 & 0 & 1 & 0 \\
\hline \multirow[t]{2}{*}{ Sample size } & & 1 & 2 & 3 & 3 & 2 & 3 & 3 & 4 & 2 & 1 \\
\hline & A & 0.00 & 0.00 & 0.00 & 0.00 & 0.00 & 0.16 & 0.33 & 0.50 & 0.00 & 0.00 \\
\hline \multirow[t]{3}{*}{ PEP-LGG I } & $\mathrm{B}$ & 0.00 & 0.00 & 0.33 & 0.00 & 0.00 & 0.83 & 0.66 & 0.37 & 0.50 & 0.00 \\
\hline & C & 1.00 & 1.00 & 0.66 & 1.00 & 1.00 & 0.00 & 0.00 & 0.12 & 0.00 & 0.00 \\
\hline & D & 0.00 & 0.00 & 0.00 & 0.00 & 0.00 & 0.00 & 0.00 & 0.00 & 0.50 & 1.00 \\
\hline Character state & & 3 & 3 & 3 & 3 & 3 & 2 & 2 & 1 & 1 & 0 \\
\hline \multirow[t]{3}{*}{ Sample size } & & 1 & 2 & 3 & 3 & 1 & 3 & 3 & 4 & 1 & 1 \\
\hline & A & 0.00 & 0.00 & 0.00 & 0.16 & 0.00 & 0.00 & 0.33 & 0.00 & 0.00 & 0.00 \\
\hline & B & 0.00 & 1.00 & 0.00 & 0.50 & 0.00 & 0.00 & 0.00 & 0.00 & 1.00 & 0.00 \\
\hline \multirow[t]{3}{*}{ PEP-LGG2 } & C & 0.00 & 0.00 & 1.00 & 0.33 & 1.00 & 1.00 & 0.66 & 0.00 & 0.00 & 0.00 \\
\hline & $\mathrm{D}$ & 1.00 & 0.00 & 0.00 & 0.00 & 0.00 & 0.00 & 0.00 & 1.00 & 0.00 & 0.00 \\
\hline & $\mathrm{E}$ & 0.00 & 0.00 & 0.00 & 0.00 & 0.00 & 0.00 & 0.00 & 0.00 & 0.00 & 1.00 \\
\hline Character state & & 2 & 1 & 3 & 1 & 3 & 3 & 3 & 2 & 1 & 2 \\
\hline \multirow[t]{3}{*}{ Sample size } & & 1 & 2 & 3 & 3 & 2 & 3 & 3 & 4 & 1 & 1 \\
\hline & $\mathrm{A}$ & 0.00 & 0.00 & 0.00 & 0.00 & 0.00 & 0.00 & 0.00 & 0.00 & 0.00 & 1.00 \\
\hline & B & 0.00 & 0.00 & 0.33 & 0.00 & 0.50 & 0.33 & 0.33 & 0.00 & 0.00 & 0.00 \\
\hline \multirow[t]{2}{*}{ MDH-1 } & $\mathrm{C}$ & 1.00 & 1.00 & 0.66 & 1.00 & 0.50 & 0.66 & 0.66 & 1.00 & 0.00 & 0.00 \\
\hline & $\mathrm{D}$ & 0.00 & 0.00 & 0.00 & 0.00 & 0.00 & 0.00 & 0.00 & 0.00 & 1.00 & 0.00 \\
\hline Character state & & 2 & 2 & 2 & 2 & 9 & 2 & 2 & 2 & 1 & 0 \\
\hline Sample size & & 1 & 2 & 3 & 3 & 2 & 3 & 3 & 4 & 2 & 1 \\
\hline \multirow[t]{2}{*}{ MDH-2 } & A & 0.00 & 0.00 & 0.00 & 0.00 & 0.00 & 0.00 & 0.00 & 0.00 & 1.00 & 1.00 \\
\hline & B & 1.00 & 1.00 & 1.00 & 1.00 & 1.00 & 1.00 & 1.00 & 1.00 & 0.00 & 0.00 \\
\hline Character state & & l & 1 & 1 & 1 & 1 & 1 & 1 & 1 & 0 & 0 \\
\hline
\end{tabular}

\section{Phylogenetic analysis}

Phylogenetic and statistic analyses were performed on a microcomputer and a mainframe VAX-8650 computer at the University of New Mexico. The statistical packages, Biostat II (Pimentel and Smith, 1986) and SAS (Statistical Analysis Systems, Cary NC.), were used to examine frequency distributions, test normality, and produce univariate statistics for morphologic characters. The computer program PAUP 2.4.1 (Phylogenetic Analysis Using Parsimony, Swofford, 1985) was used to generate phylogenetic hypotheses by numerical cladistic analysis. BIOSYS-I (Swofford \& Selander, 1981) was used to summarize frequencies of alleles at each locus for each OTU.

For quantitative phylogenetic analysis using morphological characters, missing data for individuals were estimated using a standard regression equation. 
If more than five characters for an individual were lacking, the individual was dropped from the analysis. To reduce possible non-phylogenetic 'noise' in the analysis caused by sexual dimorphism of the hosts (Ctenomys), only adult females were used for coding of qualitative and quantitative characters.

Thorpe (1984), Archie (1985), Chappill (1989) and Farris (1990) provided summaries and discussed justifications of the method of gap-coding used in this study. Gap-coding (sensu Mickevich \& Johnson, 1976) and generalized gapcoding (sensu Archie, 1985) were used to generate discrete character-variables from the data matrix of mensural characters. Similar results were obtained using both methods when the generalized gap-coding and standard gap-coding were used with the cutoff levels set to 1.0 and 0.5 standard deviations, respectively. The program MAPCODE 1.1 (Archie, 1988) was used to calculate univariate statistics on each character of each OTU, gap-code each character at $0.5 \mathrm{SD}$ units as the cutoff point, assign each OTU to the proper character group (i.e. group of OTUs that are similar within $0.5 \mathrm{SDs}$ ) and code the groups using integer coding. This procedure was repeated for each character.

Phylogenetic analysis was conducted using the principle of maximum parsimony as the optimizing criterion with the computer program PAUP 2.4.1 (Swofford, 1985). Thus, the tree that is the shortest also has the least homoplasy and the fewest ad-hoc explanations necessary to explain the evolution of each character on the tree in question. The consistency index (CI) (cf. Kluge \& Farris, 1969; Farris, 1989) of each tree was calculated as a measure of the amount of homoplasy present in the cladogram. Characters that were uniformative in a phylogenetic sense (i.e. autapomorphies that were nonhomoplasies) were deleted before the analysis.

Several different character sets (i.e. qualitative morphological and karyotypic, allozymic and quantitative) were used in the analyses; therefore, I scaled all characters to equal weights during the analysis. For example, the quantitative gap-coded mensural characters with many different character states each have the same weight in the analysis as those characters with just two states. I used this option consistently in all analyses that used combined and fundamentally different character data sets. This procedure alleviates to some degree the theoretical problems that arise when gap-coding of quantitative-mensural characters is considered. Since the cutoff level for the quantitative gap-coding procedure is determined in an arbitrary fashion (i.e. to achieve some adequate level of separation of taxa) scaling the weights of all characters prevents those characters with many different character-states from swamping those with fewer states.

Outgroup comparison (Watrous \& Wheeler, 1981; Maddison, Donoghue \& Maddison, 1984) was used to root all trees and determine polarity of characters. Tests of monophyly of the ingroup were conducted by defining only one outgroup OTU as a hypothetical ancestor and allowing the rest of the outgroups to 'float'.

In the test of hypotheses concerning phyletic coevolution, I used parsimony mapping (Brooks 1981, 1985, 1988; also see O'Grady \& Deets, 1987) to superimpose the cladogram of the parasites on the cladogram of the host. In this case the parasite tree is being mapped onto the host tree, therefore the standard of reference is the host tree. The minimum number of steps required to build the host tree divided by the number of steps required to map the parasite tree onto 
the host tree indicates the amount of homoplasy present between the two trees and allows one to calculate a CI value; the closer to 1.0 the $\mathrm{CI}$, the more the two trees are concordant in their topological patterns.

\section{Hosls}

Octodontid rodents of the genera Octodon Bennett, Aconaemys Ameghino, and Spalacopus Wagner were used as outgroups to the six species of Ctenomys from Bolivia (see Appendix 1, Table 1). Including as outgroups the representatives of three genera of the inferred sister taxon of the Ctenomyidae (i.e. the Octodontidae) served to polarize character-states and confirm the monophyletic nature of the ingroup (Maddison et al., 1984).

\section{Parasites}

The nematodes Ascaridia galli (Schrank, 1788) and Helerakis sp. (Dujardin, 1845) were used as outgroups for allozyme characters to species of the genus Paraspidodera. Because data concerning protein electrophoresis (i.e. allozyme characters) for the species of Paraspidodera from Cavia sp. were not available, two hypothetical ancestors were constructed from the following taxa: Morphological characters of the nematodes Paraspidodera uncinata (Rudolphi, 1819) from Cavia porcellus and $P$. uncinata from Cavia aperea were combined with allozyme characters from Ascaridia and Heterakis, respectively (see Appendices 1, 3 and Tables 1, 4, 6). In addition, morphological data from nematodes of the genus Paraspidodera from an unidentified species of Cavia from the US National Museum were included in the analysis with the allozyme character information denoted as missing during the analysis (see Appendix 3, Tables 1,6). The single OTU ('PHYPANC') was used to root the tree using the ancester rooting option in PAUP.

Descriptions of data matrices. Several different data sets were used during this study. In the case of data that were gap-coded (quantitative data Tables 3, 7; Appendices 2, 3) the lowest number in a coding sequence for a single character represents the smallest value of that character. See Appendices 2, 3 for descriptions of the complete coding for all morphologic characters of the hosts and parasites, respectively.

For the nematodes only, a data matrix (Table 7) was prepared from qualitative (male and female characters), gap-coded quantitative characters for both males and females, and allozyme characters (from Table 6) coded using the locus-as-character qualitative integer method described above (see Appendix 3 for actual codes of all morphologic characters of nematodes used in this analysis).

\section{RESULTS}

\section{Hosts}

No well-defined rigorous cladistic analysis of all genera of hystricognath rodents from the Neotropics has been published. Relationships of species distributed among various families will, therefore, be estimated primarily from the cladogram of Woods (1982) (Fig. 1). Although the ctenomyids were not 


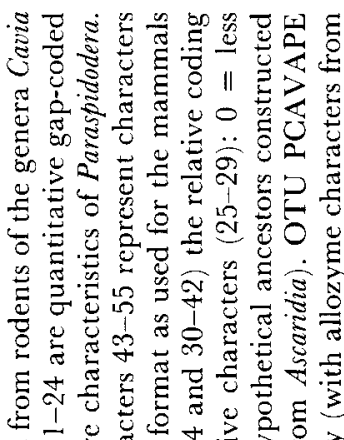

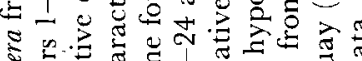

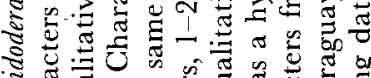

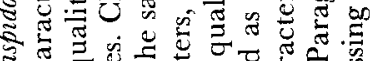

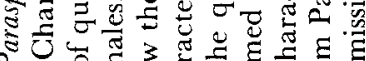

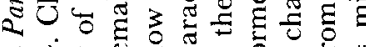

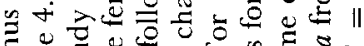

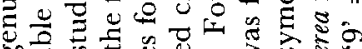
का क

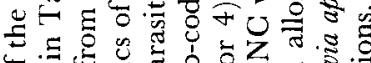

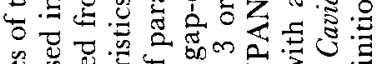

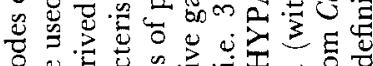

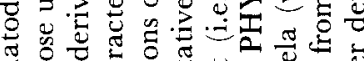

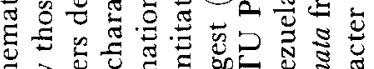

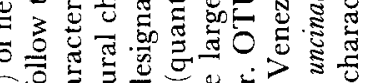
बे

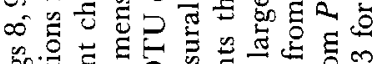

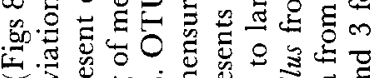

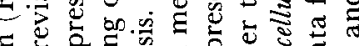

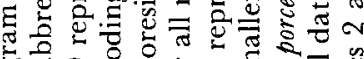

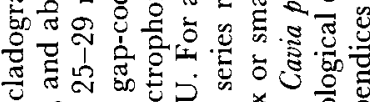

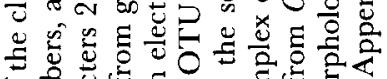

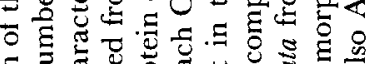

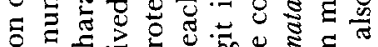

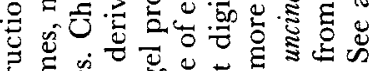

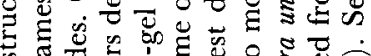

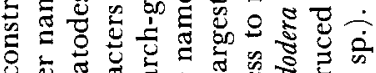
ठ क्ष

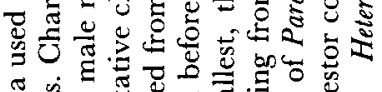
离

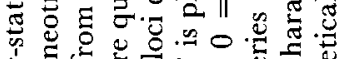

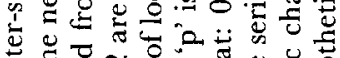

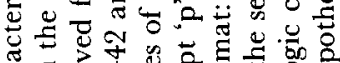

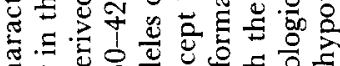

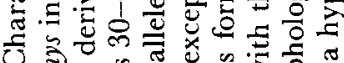
ठ हो की ने

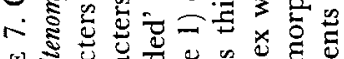

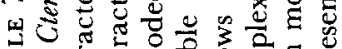

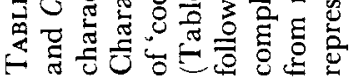

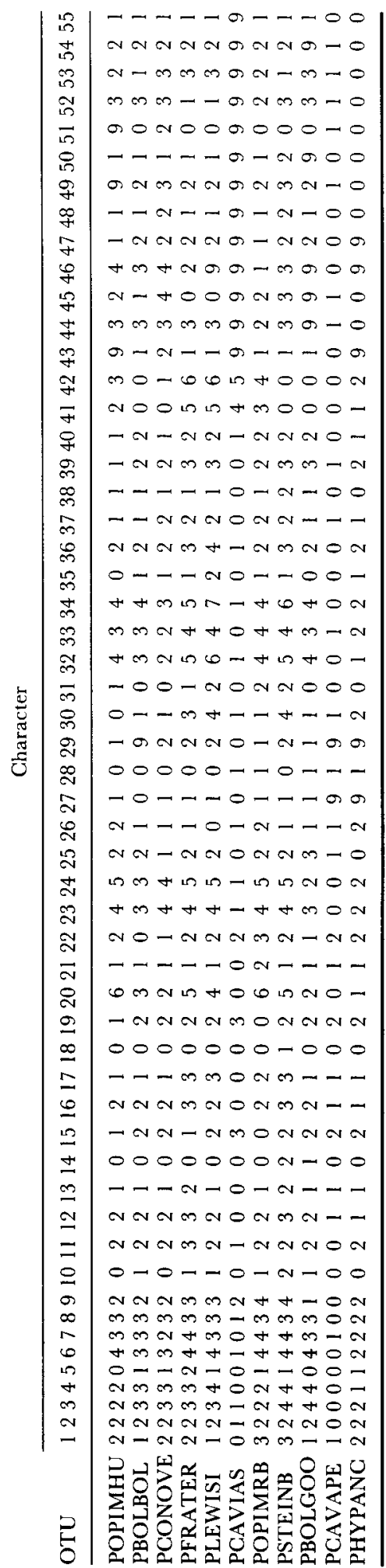




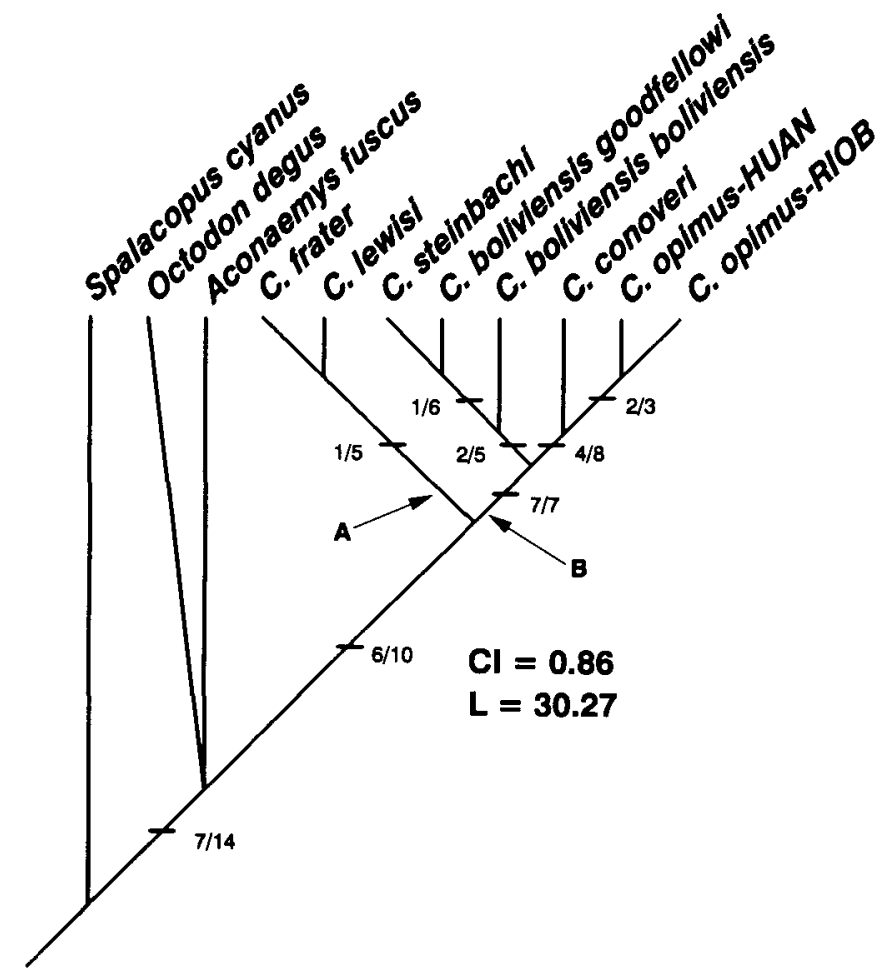

Figure 7. Cladogram of Ctenomys and outgroups based on quantitative, qualitative and chromosomal data from input data matrix (Table 7). The consistency index of this tree is 0.86 with a length of 30.27 . The numbers on the major branches represent the number of unreversed synapomorphic characters defining that branch over the total number of synapomorphies for that branch.

included in his analysis, data from morphology support the view that the octodontids and the ctenomyids are sister taxa (Reig \& Spotorno, 1972; Simpson, 1980; Reig, 1986). For Figure 1, I therefore tentatively placed the ctenomyid lineage with the octodontids (indicated with a dashed line and a question mark).

Phylogenetic relationships among the six species and two pairs of sub-OTUs (from different collecting localities) of Ctenomys from Bolivia were estimated using data derived from analysis of qualitative, chromosomal and quantitative gapcoded mensural characters for each species (Table 3, Appendix 2). The most parsimonious cladogram obtained of the host group $($ Fig. 7$)(\mathrm{CI}=0.86)$ places the clade with $C$. frater, and $C$. lewisi at the base of the tree. The branch uniting frater and lexwisi labelled ' $\mathrm{A}$ ' in Fig. 7 is confirmed by one and five unreversed and total synapomorphies, respectively. The rest of the cladogram, denoted by branch ' $\mathrm{B}$ ' (defined by seven total and seven unreversed synapomorphies) is composed of two major clades, one of which includes the large bodied 'Chacoan' C. conoveri as the sister taxon of C. opimus (confirmed with four and eight unreversed and total synapomorphies, respectively). The other major clade comprises the OTUs $C . b$. boliviensis, $C . b$. goodfellowe $i$ and $C$. steinbachi, confirmed by two unreversed and five total synapomorphies, respectively. 


\section{Nematode parasites}

Of the 13 loci examined among the outgroup and ingroup taxa of mematodes, all were polymorphic across OTUs. For all ingroup OTUs, the mean number of alleles per locus was 1.4 and the percent loci that were polymorphic was $32.73 \%$. Average individual heterozygosity $(\mathbf{H})$ in the eight ingroup OTUs ranged from 0.038 to 0.192 with an overall mean value of 0.114 . The level of genetic differentiation among OTUs of parasites derived from the same species of host but from different localities was not great; only the peptidase locus PEP-LGG2 was fixed for different alleles in OTUs PBOLBOL and PBOLGFE. The OTUs POPIMHU and POPIMRB (both derived from the same species of host, C. opimus) shared alleles at all loci.

Phylogenetic analysis of data derived from allozyme electrophoresis of individual nematodes (Table 7, characters 43-55) produced 62 equally parsimonious trees $(\mathrm{L}=11.5, \mathrm{CI}=0.884)$. The information in these trees was summarized with an Adams consensus tree (Fig. 8A) and this was used for comparison with the results of the morphological analysis (see below).

Of the 43 morphological characters (Table 7, characters 1-43) used in the analysis, 38 were quantitative gap-coded mensural characters and five were qualitative (integer-coded) characters.

\section{Congruence: biochemical vs. morphological data}

To facilitate comparisons between cladograms developed from biochemical and morphological data, the two outgroup taxa were removed. The consensus cladogram for the parasites developed from biochemical-genetic data (Fig. 8A; $\mathrm{L}=12.08 ; \mathrm{CI}=0.924$ ) was compared with the reduced OTU cladogram produced from analysis of morphological data (Fig. 8B; L = 39.51; CI = 0.758 ) using both the Mickevich-Farris character incongruence statistic $I_{\mathrm{MF}}$ (Mickevich \& Farris, 1981; Kluge, 1989) and parsimony mapping (Brooks, 1988) (see Table 8). To facilitate the analyses, the biochemical-morphological data-sets were combined and re-analysed with PAUP to produce another cladogram (Fig. 8C; $\mathrm{L}=51.93 ; \mathrm{CI}=0.776$ ). This 'combined' cladogram has 11.63 extra steps. Of these extra steps, 0.92 result from the genetic data-set and 9.56 result from the morphological data-set. These 10.48 extra steps represent the total incongruence between separale data-sets. This leaves a total of 1.15 steps or $I_{\mathrm{MF}}=10.09 \%$ that represents the percentage total incongruence caused by combining the data-sets and analysing them as one single data-set (Table 8). The incongruence between character-sets (percent incongruence between character-sets) is $2.24 \%$. Although few studies concerning character incongruence (that utilize $I_{\mathrm{MF}}$ statistics) exist that can be directly compared, the present result of relatively high concordance between the biochemical-genetic and the morphologic data-sets relative to the incongruence among characters within each set approximates the result of Kluge (1989) for snakes.

Parsimony mapping of the biochemical tree to the morphological tree, using the morphological tree as the reference (Fig. 8D, Tables 8, 9) revealed that there is a discordance between the topological patterns as measured by the CI of $14 / 17=82.36 \%$. Part of the congruence between the trees may be stochastic because of an increase in the CI attributable to the polytomy in the 

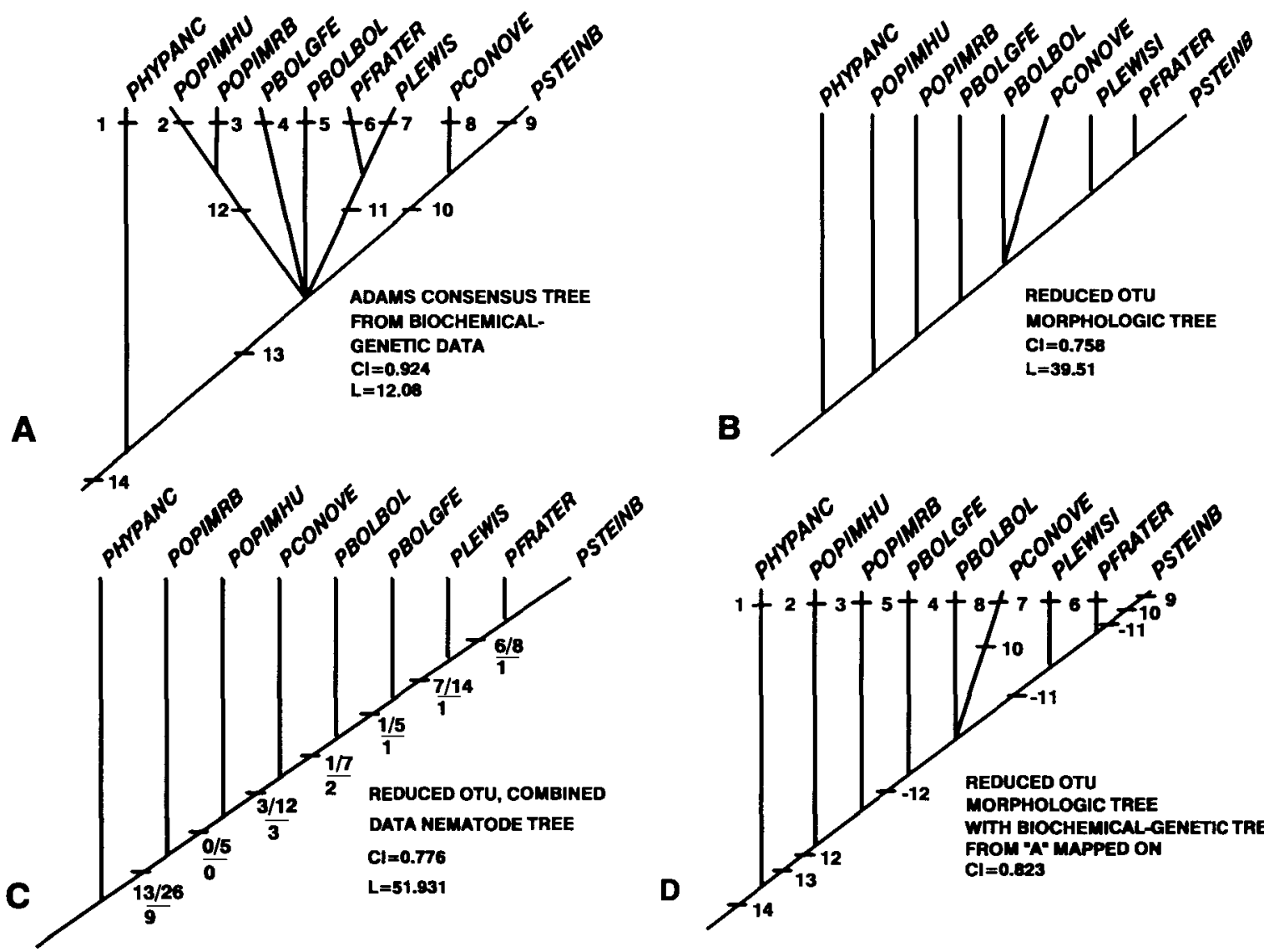

Figure 8. A, Adams consensus cladogram of 62 most parsimonious trees developed from the reduced OTU biochemical-genetic data set (Table 7). B, Cladogram developed from the full data set (all OTUs included) of only the morphological characters of the nematodes. C, Reduced taxon combined cladogram derived from analysis of both morphologic and electrophoretic data of Paraspidodera nematodes. The numbers of the tree represent the numbers of unreversed synapomorphies over the total number of synapomorphies with the number of synapomorphic electrophoretic characters shown below. D, Reduced taxon parasite (Paraspidodera) morphologic cladogram with parasite biochemical-genetic tree mapped on using parsimony mapping. For details, see Table 8 and text.

biochemical-genetic consensus tree (Fig. 8A). In Table 8 it can be seen that there is a disparity of about $15.46 \%$ between the $I_{\mathrm{MF}}$ statistic and the CI derived from the parsimony mapping method; however, the methods may not be directly comparable because of the emphasis on character incongruence with the $I_{\mathrm{MF}}$ statistic and topological congruence with parsimony mapping. For these types of comparisons it appears that parsimony mapping is easier to interpret and does take into account 'total evidence' (Kluge, 1989).

\section{Phylogenetic congruence - hosts and parasites}

The parasite cladogram (Fig. 9A) was the single most parsimonious tree produced from analysis of 55 characters from the input matrix (Table 7) (42 morphological and 13 biochemical-genetic characters). To affirm the 
TABLE 8. Summary of character-congruence information for the biochemical vs. morphologic data sets of nematodes of the genus Paraspidodera. See text for details

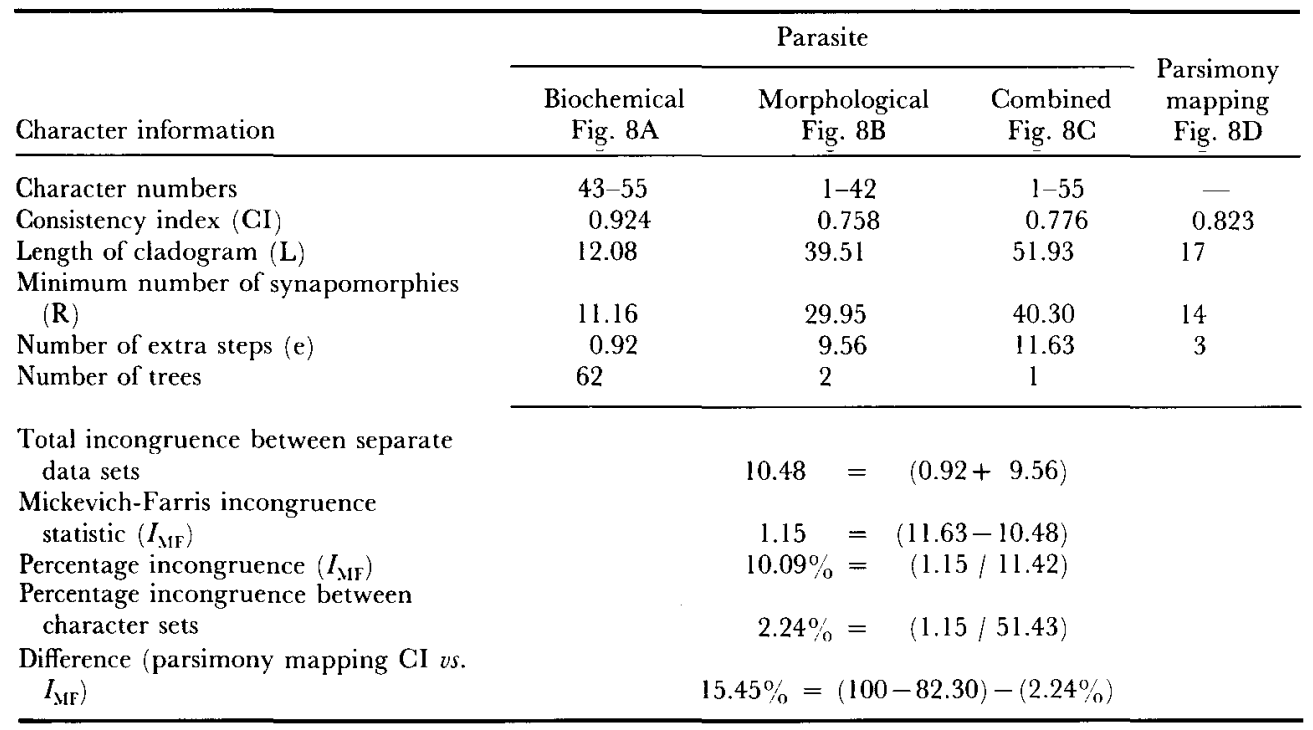

monophyletic nature of Paraspidodera from Ctenomys, all three outgroup taxa were included in the development of the trees used for host-parasite comparisons (Maddison et al., 1984). After the final topological pattern was established, the outgroups were then combined into a single OTU for parsimony mapping (Fig. 9B).

The cladogram of the parasites (with all outgroups included) $(\mathrm{L}=72.98$; CI $=0.754$; Fig. 9A) was used as the best estimate of the phylogenetic relationships of the nematodes and is used for all further comparisons with the cladograms of the host group.

To examine coevolution among Paraspidodera and Ctenomys, I compared the

TABLE 9. Matrix of 'new' binary characters representing the cladogram of the nematodes from analysis of the biochemical-genetic data (Fig. 8A)

\begin{tabular}{|c|c|c|c|c|c|c|c|c|c|c|c|c|c|c|c|}
\hline & \multirow{3}{*}{ OTU } & \multicolumn{14}{|c|}{ New binary characters } \\
\hline & & 1 & 2 & 3 & 4 & 5 & 6 & 7 & 8 & 9 & 10 & 11 & 12 & 13 & 14 \\
\hline & & A & $\vec{B}$ & $\mathrm{C}$ & D & $\mathrm{E}$ & $\mathrm{F}$ & $\mathrm{G}$ & $\mathrm{H}$ & I & $\mathrm{J}$ & $\mathrm{K}$ & $\mathrm{L}$ & $\mathbf{M}$ & $\mathrm{N}$ \\
\hline 1 & ${ }^{*} P H Y P A N C$ & 1 & 0 & 0 & 0 & 0 & 0 & 0 & 0 & 0 & 0 & 0 & 0 & 0 & 1 \\
\hline 2 & POPIMHU & 0 & 1 & 0 & 0 & 0 & 0 & 0 & 0 & 0 & 0 & 0 & 1 & 1 & 1 \\
\hline 3 & POPIMRB & 0 & 0 & 1 & 0 & 0 & 0 & 0 & 0 & 0 & 0 & 0 & 1 & 1 & 1 \\
\hline 4 & $P B O L G F E$ & 0 & 0 & 0 & 1 & 0 & 0 & 0 & 0 & 0 & 0 & 0 & 0 & 1 & 1 \\
\hline 5 & $P B O L B O L$ & 0 & 0 & 0 & 0 & 1 & 0 & 0 & 0 & 0 & 0 & 0 & 0 & 1 & 1 \\
\hline 6 & PFRATER & 0 & 0 & 0 & 0 & 0 & 1 & 0 & 0 & 0 & 0 & 1 & 0 & 1 & 1 \\
\hline 7 & PLEWISI & 0 & 0 & 0 & 0 & 0 & 0 & 1 & 0 & 0 & 0 & 1 & 0 & l & l \\
\hline 8 & PCONOVE & 0 & 0 & 0 & 0 & 0 & 0 & 0 & l & 0 & 1 & 0 & 0 & 1 & l \\
\hline 9 & PSTEINB & 0 & 0 & 0 & 0 & 0 & 0 & 0 & 0 & 1 & 1 & 0 & 0 & 1 & 1 \\
\hline 10 & HTU-10 & 0 & 0 & 0 & 0 & 0 & 0 & 0 & 0 & 0 & l & 0 & 0 & 1 & 1 \\
\hline 11 & HTU-11 & 0 & 0 & 0 & 0 & 0 & 0 & 0 & 0 & 0 & 0 & 1 & 0 & 1 & 1 \\
\hline 12 & HTU-12 & 0 & 0 & 0 & 0 & 0 & 0 & 0 & 0 & 0 & 0 & 0 & 1 & i & 1 \\
\hline 13 & HTU-13 & 0 & 0 & 0 & 0 & 0 & 0 & 0 & 0 & 0 & 0 & 0 & 0 & 1 & 1 \\
\hline 14 & HTU-14 & 0 & 0 & 0 & 0 & 0 & 0 & 0 & 0 & 0 & 0 & 0 & 0 & 0 & 1 \\
\hline
\end{tabular}



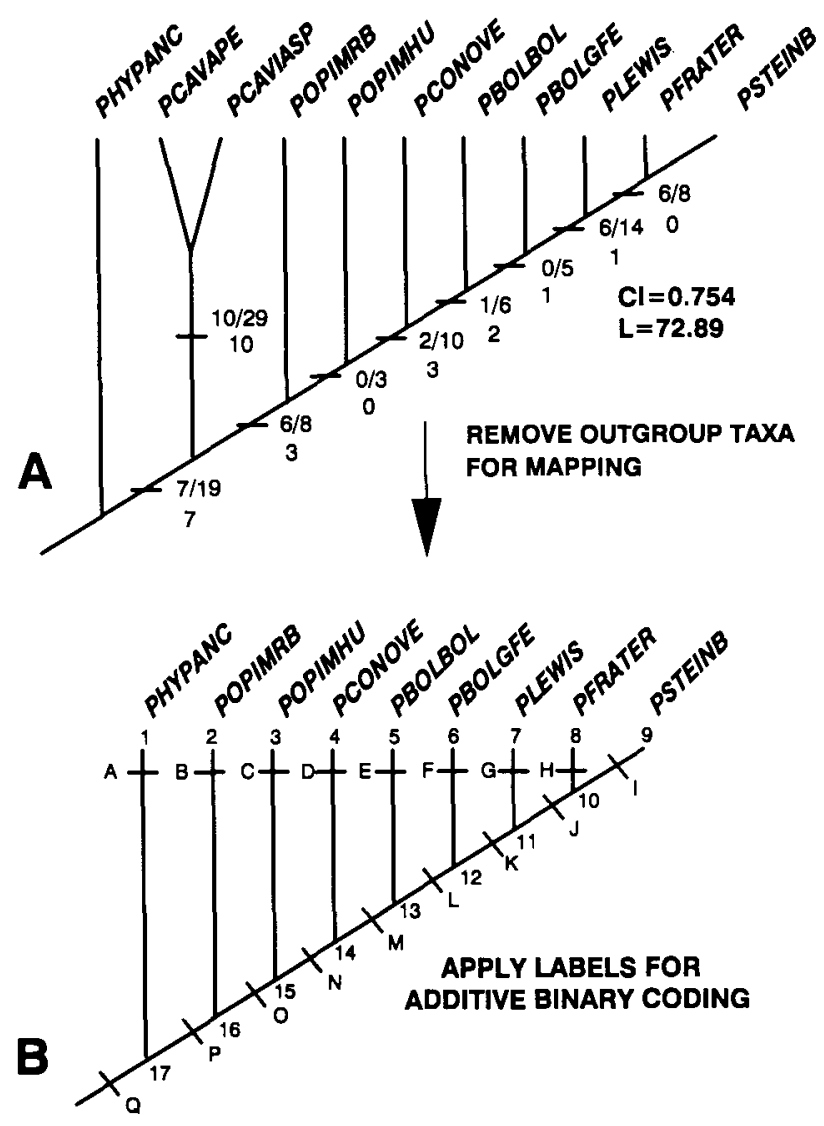

\begin{abstract}
Figure 9. A, Combined cladogram (morphological and biochemical-genetic data) with all nematode OTUs included (see Table 7). The figures on the major branches represent the number of unreversed synapomorphic characters defining that branch over the total number of synapomorphies for that branch, the third figure below represents the number of electrophoretic characters defining each branch. B, Reduced branch combined cladogram of Paraspidodera. The number of taxa (terminal branches) have been reduced to facilitate parsimony mapping to the host cladogram. The nodes and branches were labelled to allow additive binary coding of this tree into a matrix of binary variables (Table 10 ).
\end{abstract}

cladogram developed for the hosts with the cladogram of the parasites using parsimony mapping (Brooks, 1985). To facilitate mapping, the number of terminal branches of the cladograms to be compared must be equal, therefore the two outgroups were combined into one on both host and parasite trees. The reduced taxon (outgroups combined) parasite tree (Fig. 9B) retains the overall phylogenetic information of the ingroup taxa (Fig. 9A). The cladogram of the nematodes (Fig. 9B) was converted into a matrix of binary characters (Table 10) and mapped to the cladogram of the host (Fig. 10). The results $(\mathrm{L}=17 ; \mathrm{R}=24$ ( $\mathrm{R}=$ total number of characters mapped to tree $) ; \mathrm{CI}=$ 0.708; Fig. 10) shows the host cladogram with the parasite tree (From Fig. 9B) 'mapped' to it. The null hypothesis of random colonization of hosts by their nematode parasites was falsified (Fig. 10); however, neither were the cladograms of mammals and the nematodes completely congruent.

The Mickevich-Farris incongruence statistic was also applied in comparisons 
TABLE 10. Matrix of 'new' binary characters representing the "reduced branch" cladogram of the parasites (Fig. 9B)

\begin{tabular}{|c|c|c|c|c|c|c|c|c|c|c|c|c|c|c|c|c|c|}
\hline \multirow{3}{*}{ OTU } & \multicolumn{17}{|c|}{ New binary characters } \\
\hline & 1 & 2 & 3 & 4 & 5 & 6 & 7 & 8 & 9 & 10 & 11 & 12 & 13 & 14 & 15 & 16 & 17 \\
\hline & A & $\mathrm{B}$ & C & $\mathbf{D}$ & $\mathbf{E}$ & $\mathbf{F}$ & $\mathrm{G}$ & $\mathrm{H}$ & I & $\mathrm{J}$ & $\mathrm{K}$ & $\mathrm{L}$ & $\mathbf{M}$ & $\mathrm{N}$ & $\mathrm{O}$ & $\mathrm{P}$ & $Q$ \\
\hline I PHYPANC & 1 & 0 & 0 & 0 & 0 & 0 & 0 & 0 & 0 & 0 & 0 & 0 & 0 & 0 & 0 & 0 & 1 \\
\hline $2 P O P I M R B$ & 0 & 1 & 0 & 0 & 0 & 0 & 0 & 0 & 0 & 0 & 0 & 0 & 0 & 0 & 0 & 1 & 1 \\
\hline 3 POPIMHU & 0 & 0 & l & 0 & 0 & 0 & 0 & 0 & 0 & 0 & 0 & 0 & 0 & 0 & 1 & l & 1 \\
\hline 4 PCONOVE & 0 & 0 & 0 & 1 & 0 & 0 & 0 & 0 & 0 & 0 & 0 & 0 & 0 & l & 1 & 1 & l \\
\hline $5 P B O L B O L$ & 0 & 0 & 0 & 0 & 1 & 0 & 0 & 0 & 0 & 0 & 0 & 0 & 1 & 1 & 1 & 1 & 1 \\
\hline 6 PBOLGFE & 0 & 0 & 0 & 0 & 0 & 1 & 0 & 0 & 0 & 0 & 0 & 1 & 1 & 1 & 1 & 1 & 1 \\
\hline 7 PLEWISI & 0 & 0 & 0 & 0 & 0 & 0 & 1 & 0 & 0 & 0 & 1 & l & 1 & 1 & 1 & 1 & 1 \\
\hline 8 PFRATER & 0 & 0 & 0 & 0 & 0 & 0 & 0 & 1 & 0 & 1 & l & 1 & 1 & 1 & 1 & 1 & 1 \\
\hline $9 P S T E I \mathcal{N} B$ & 0 & 0 & 0 & 0 & 0 & 0 & 0 & 0 & 1 & 1 & 1 & l & l & 1 & 1 & 1 & 1 \\
\hline $10 \mathrm{HTU}-10$ & 0 & 0 & 0 & 0 & 0 & 0 & 0 & 0 & 0 & 1 & 1 & 1 & 1 & 1 & 1 & 1 & 1 \\
\hline $11 \mathrm{H} T \mathrm{U}-11$ & 0 & 0 & 0 & 0 & 0 & 0 & 0 & 0 & 0 & 0 & 1 & l & 1 & 1 & 1 & 1 & 1 \\
\hline 12 HTU-12 & 0 & 0 & 0 & 0 & 0 & 0 & 0 & 0 & 0 & 0 & 0 & 1 & 1 & 1 & 1 & l & 1 \\
\hline 13 HTU -13 & 0 & 0 & 0 & 0 & 0 & 0 & 0 & 0 & 0 & 0 & 0 & 0 & 1 & 1 & 1 & 1 & 1 \\
\hline $14 \mathrm{HTU}-14$ & 0 & 0 & 0 & 0 & 0 & 0 & 0 & 0 & 0 & 0 & 0 & 0 & 0 & 1 & 1 & 1 & l \\
\hline 15 HTU-15 & 0 & 0 & 0 & 0 & 0 & 0 & 0 & 0 & 0 & 0 & 0 & 0 & 0 & 0 & 1 & 1 & 1 \\
\hline $16 \mathrm{HTU}-16$ & 0 & 0 & 0 & 0 & 0 & 0 & 0 & 0 & 0 & 0 & 0 & 0 & 0 & 0 & 0 & 1 & 1 \\
\hline 17 HTU-17 & 0 & 0 & 0 & 0 & 0 & 0 & 0 & 0 & 0 & 0 & 0 & 0 & 0 & 0 & 0 & 0 & 1 \\
\hline
\end{tabular}

of the host and parasite cladograms (Table 11). Percent 'character incongruence' as measured by the $I_{\mathrm{MF}}$ was $14.46 \%$. The number of extra steps resulting when the data matrices of both hosts and parasites were combined and analysed was 3.49 and is considerably less than the seven extra steps revealed by parsimony mapping.

\section{DISCUSSION}

\section{Phyletic coevolution}

In the present case, one most parsimonious interpretation of phyletic coevolution can be postulated. In Fig. 10, three losses or extinctions of ancestral

Table 11. Summary of congruence and incongruence statistics for the Ctenomys-Paraspidodera host-parasite system. See Kluge (1989) and text for details on calculating the different measures of congruence and incongruence

\begin{tabular}{|c|c|c|c|c|}
\hline $\begin{array}{l}\text { Cladogram and character } \\
\text { congruence information }\end{array}$ & Host & Parasite & $\begin{array}{l}\text { Host-parasite } \\
\text { parsimony mapped }\end{array}$ & $\begin{array}{l}\text { Host-parasite } \\
\text { combined }\end{array}$ \\
\hline \multicolumn{5}{|l|}{ Character numbers } \\
\hline Consistency index $(\mathrm{CI})$ & 0.859 & 0.771 & 0.7083 & 0.772 \\
\hline Length of cladogram (L) & 30.26 & 71.45 & 17 & 104.63 \\
\hline \multicolumn{5}{|l|}{ Minimum number of } \\
\hline synapomorphies (R) & 26 & 55.02 & 24 & 80.18 \\
\hline Number of extra steps (c) & 4.2 & 16.44 & 7 & 23.81 \\
\hline Number of trees & 3 & 1 & $\cdots$ & 1 \\
\hline \multicolumn{3}{|l|}{ Total incongruence between } & & \\
\hline $\begin{array}{l}\text { Mickevich-Farris incongruence } \\
\text { statistic }\left(I_{\mathrm{MIF}}\right)\end{array}$ & $3.49=$ & $=(24.13-20.64)$ & & \\
\hline Percentage incongruence $\left(I_{\mathrm{MIF}}\right)$ & $14.46^{\circ}=$ & $=(3.49 / 24.13)$ & & \\
\hline
\end{tabular}




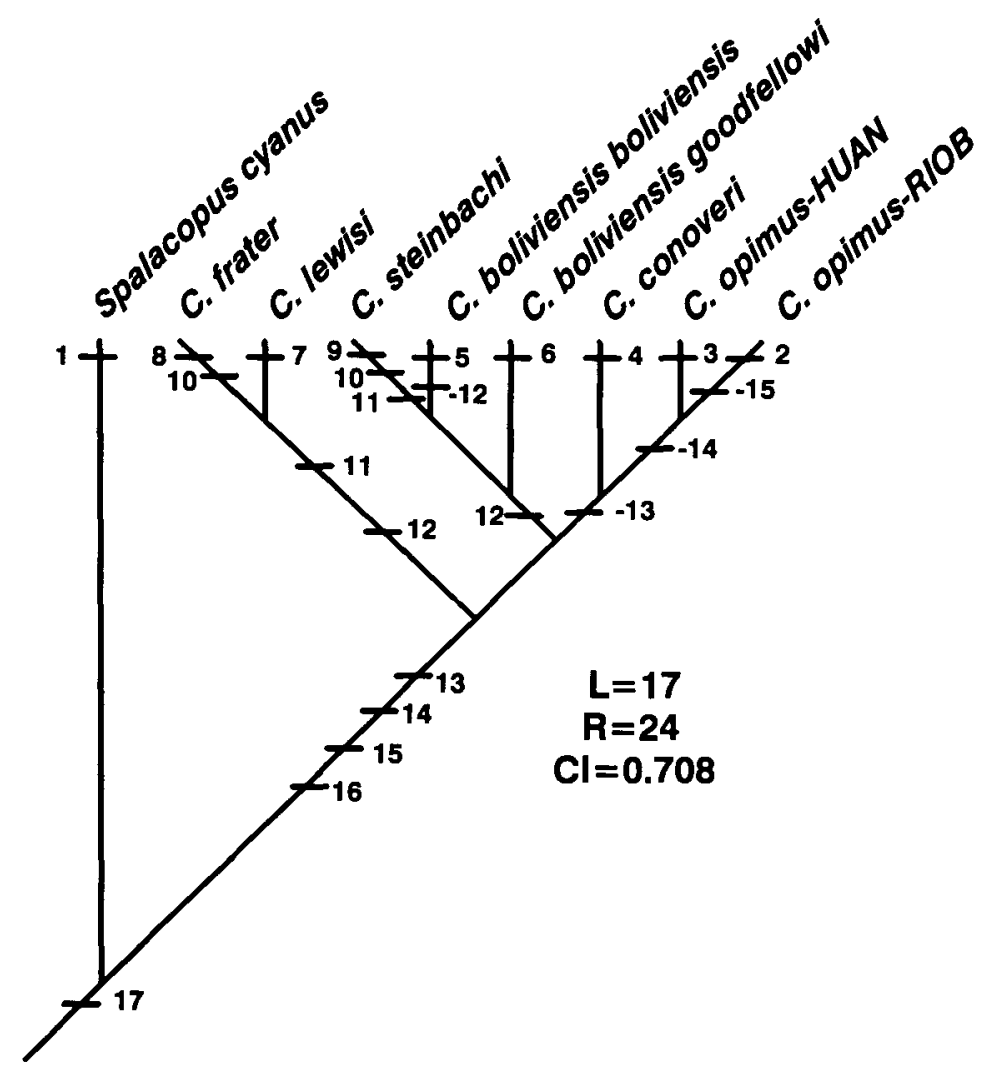

Figure 10. Result of mapping the tree representing the relationships of Paraspidodera (Fig. 10B) onto the reduced OTU cladogram of Cienomys (Fig. 7). See Table 11 for descriptive statistics.

parasite lineages (HTUs 13, 14, 15) occurred along the branches giving rise to $C$. conoveri and the two sub-OTUs of $C$. opimus along with another loss of parasite HTU 12 from $C . b$. boliviensis. In addition, the following host-switches occurred: Ancestral nematode parasite HTU no. 10 transferred between the extant host species C. steinbachi and C. frater; ancestral parasite HTU no. 11 transferred between $C$. steinbachi and the clade comprising both $C$. lewisi and $C$. frater, and ancestral parasite HTU no. 12 transferred between the $C$. frater, $C$. lewisi clade and the clade comprising $C$. steinbachi, and two sub-species of $C$. boliviensis. The transfer of nematodes representing HTU nos. 10 and 11 between $C$. steinbachi and $C$. frater appears to have occurred in relatively recent geological time.

Evidence indicates that the ancestors of the nematodes in the host clades [(lewisi, frater) and ((boliviensis, steinbachi) boliviensis)] (Fig. 10) transferred among the HTUs of ancestral Ctenomys when the ranges of these rodents were coextensive in the past. The present-day geographic distributions of Ctenomyid rodents in south-central South America and Bolivia in particular (Fig. 4) are poorly known; however, our limited collections of both $C$. lewisi and $C$. frater and of both $C$. boliviensis and $C$. steinbachi indicate that $C$. lewisi and $C$. frater have ranges that are relatively close in geographic space and $C$. frater and $C$. steinbachi are species that are restricted in range to the eastern foothills of the Bolivian Andes (Fig. 4). Note also that $C$. frater reaches the northern limit of its range in 
Bolivia and has a distribution extending south into Argentina, but $C$. lewisi has been reported to occur only in one small area (Fig. 4) (Anderson et al., 1987).

Comparing host and parasite cladograms using parsimony mapping (Brooks' method) provided detailed information on exact incongruencies between the trees in question. No other tree comparison techniques provide this detail. Switching of parasites among host-lineages is relatively uncommon in this system; switching or host-transfer of ancestral nematodes (HTUs) occurred only among the ancestors in the clade comprising lewisi and frater to or from the ancestral species giving rise to $C$. steinbachi, and the two OTUs of C. boliviensis.

Rodents that occupy a subterranean ectotope occur in disjunct colonies, presumably have relatively low vagility, and are known to show relatively high levels of genetic divergence within and among species (Nevo, 1976; Patton \& Smith, 1989); therefore, the nematodes in populations of Ctenomys and other subterranean rodents are probably subject to similar evolutionary pressures. Losses of parasites in a lineage of hosts may be due to a 'founder effect'. This type of loss of parasite lineages may occur more commonly in rodents with a subterranean life-habit than in other rodents which have larger ranges and may not be as restricted in vagility. Host-switching in this specific system appears less probable because of the usual allopatry that is observed in distributions of species of Ctenomys.

\section{Timescales and host-switching by parasites}

Nematodes of the family Aspidoderidae occur only in neotropical mammals and are common in marsupials and xenarthrans as well as in hystricognath rodents. Because of this sharing of taxa of nematodes, it is probable that ancestors of aspidoderid nematodes evolved primarily in marsupials and xenarthrans and that the precursors of nematodes of the genus Paraspidodera transferred to rodents some time after the arrival of the hystricognath rodents in the Neotropics (about 38 mya) (Fig. 11).

It is evident that the ancestors of those species of Paraspidodera presently occurring in caviids also gave rise to the decendants representing the monophyletic group of Paraspidodera presently extant in Ctenomys (Fig. 11A,B). Nematodes of the genus Paraspidodera have been found in individuals of each species of Ctenomys that have been adequately studied; therefore, transfer of representatives of the phylogenetic lineage of Paraspidodera from the Cavioidea to ctenomyids must have occurred before the ctenomyids had undergone much diversification. The host-switch by the nematodes (Fig. 11) probably resulted from a sympatric association between caviids and the rodents (Praectenomys spp.?) that later gave rise to representatives of the genus Ctenomys. Species assignable to the genus Ctenomys first appear in the fossil record in latest Pliocene or earliest Pleistocene time (Reig, 1986), and rodents that are recognizably 'ctenomyine' such as Praectenomys rhombidens Villarroel are found as fossils in upper Pliocene deposits in Bolivia (Villarroel, 1975).

The argument for a relatively recent transfer of nematodes from caviids to ctenomyids derives support from the fact that no aspidoderids have yet been reported from any of several genera of Octodontidae even though the diversity of helminths of Octodontid rodents (i.e. Octodon and Spalacopus) from Chile is well 


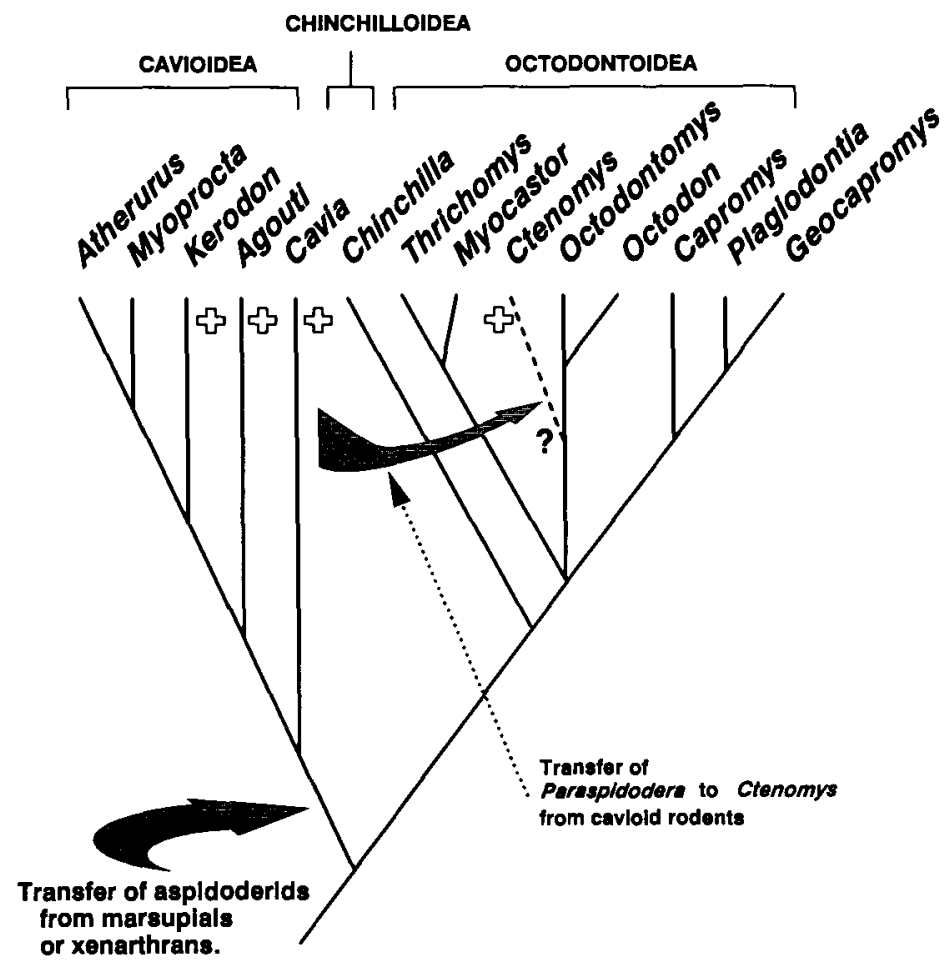

Figure 11. Cladogram depicting evolutionary relationships among selected genera of neotropical and African hystricognath rodents (from Woods, 1982). Host lineages in which nematodes of the genus Paraspidodera have been reported to occur are indicated with crosses. Transfers of these nematodes to rodents from marsupials or xenarthrans and between families of rodents are indicated by arrows and dashed lines.

known (Babero, 1980; Babero \& Cattan, 1975; Cattan, George-Nascimento \& Rodriguez, 1976; Cattan \& George, 1978).

The asymmetrical distribution of nematodes of the genus Paraspidodera in ctenomyids, caviids, cuniculids and octodontids (Babero \& Cattan, 1975) (Fig. 11) indicates that either a specific transfer of parasites to the base of a rapidly evolving clade (the ctenomyids) occurred or that the phylogenetic relationships of these rodents may not be well defined. Negative data (such as absence of parasites in the Octodontidae) cannot contribute to tests of hypotheses of phylogenetic relationships of hosts. However, nematodes of the genus Paraspidodera have been found in rodents of the genus Ctenomys each time a large series of specimens has been examined for these parasites. Is this a phylogenetic-historical accident (i.e. loss of the parasite lineage in the octodontids) or are the relationships of the Ctenomyids and Octodontids not so well defined as presently thought?

The study of phyletic coevolution of parasites and their rodent hosts is in its infancy. Rodents are ubiquitous and may be inhabited by parasites on a massive scale over large geographic distances throughout many types of habitat. Studies of rodent-parasite systems in which phylogenetic hypotheses are developed for both the host and their parasites simultaneously should serve to provide a starting point for examining questions relative to evolutionary patterns and their 
processes. Hypotheses of biogeography relative to endemism of species, cospeciation, and general patterns of speciation may be tested more completely by examining both hosts and parasites simultaneously.

\section{ACKNOWLEDGEMENTS}

This work was supported in a large part by the National Science Foundation (Grant Nos. BSR-8612329 to S. L. Gardner, T. L. Yates and D. W. Duszynski, BSR-8408923 to T. L. Yates, and BSR-8316740 to S. Anderson), the American Museum of Natural History, the Museum of Southwestern Biology, and the Tinker Foundation. Financial support was also obtained from the Latin American Institute, the University of New Mexico. The following organizations provided either specimens or logistic support in the field: El Museo National de Historia Natural, La Paz; the Museum of Southwestern Biology, the University of New Mexico; Division of Worms, Muséum National D'Histoire Naturelle, Paris; Division of Worms, Muséum National D'Histoire Naturelle, Genève; and El Instituto Boliviano de Biologia de la Altura, La Paz, Bolivia.

I thank the following people whose contributions range from collecting hosts and parasites in the field to discussions of anything from worms to cladistics: S. Bandoni, M. Campbell, A. Chabaud, F. Davis, P. Desjeux, A. Dickerman, D. Duszynski, P. Ford, W. Gannon, L. Hertel, J. P. Hugot, O. Jordan, C. Lambert, E. Loker, J. Miralles, D. Moore, N. Olds, B. Riddle, J. Salazar, G. Schmidt, C. Schuster, N. Scott, R. Thornhill and C. Vaucher.

I should especially like to thank Robert Rausch for support and encouragement, Sydney Anderson, Joseph Cook and Terry Yates for assistance throughout the project and for the use of the raw mensural data from several species of Ctenomys, and R. T. O'Grady for comments and suggestions on an earlier draft of this manuscript.

\section{REFERENCES}

ANDERSON, S., YATES, T. L. \& COOK, J. A., 1987. Notes on Bolivian Mammals 4: The genus Ctenomys (Rodentia, Ctenomyidae) in the eastern lowlands. American Museum Novitates, 2891: 1-20.

ARCHIE, J. W., 1985. Methods for coding variable morphological features for numerical taxonomic analysis. Systematic Zoology, 34: 326-345.

ARCHIE, J. W., 1988. Mapcode V 1.1. Available from James W. Archie, Dept. of Biology, California State University, Long Beach, CA 90840.

ARCHIE, J. W., SIMON C. \& MARTIN, A., 1989. Small sample size does decrease the stability of dendrograms calculated from allozyme-frequency data. Evolution, 43: 768-683.

BABERO, B. B., 1980. Helmintofauna de Chile: VIII. Graphidioides yanezi sp. n. Parasito de Spalacopus cyanus Molina (Nematoda: Trichostrongylidae). Boletin Museo Nacional de Historia Natural de Chile, 37: 225-228.

BABERO, B. B. \& CATTAN, P. E., 1975. Helmintofauna de Chile: III. Parasitos del roedor degu Octodon degus Molina, 1782 con la descripcion de tres neuvas especies. Boletin Chileno de parasitologia, 30: 68-76.

BROOKS, D. R., 1979. Testing the context and extent of host-parasite coevolution. Systematic Zoology, 28: 299-307.

BROOKS, D. R., 1981. Hennig's parasitological method: a proposed solution. Systematic Zoology, 30: $229-249$.

BROOKS, D. R., 1985. Historical ecology: A new approach to studying the evolution of ecological associations. Annals of the Missouri Botanical Garden, 72: 660-680.

BROOKS, D. R., 1988. Macroevolutionary comparisons of host and parasite phylogenies. Annual Review of Ecology and Systematics, 19: 235-259.

BROOKS, D. R. \& BANDONI, S. M., 1988. Cocvolution and relicts. Systematic Zoology, 37: 19-33.

BROOKS, D. R. \& O'GRADY, R. T., 1989. Crocodilians and their helminth parasites: macroevolutionary considerations. American Zoologist, 29: 873-883.

BUTH, D. G., 1984. The application of electrophoretic data in systematic studies. Annual Review of Ecology and Syslemalics, 15: 501-522. 
CATTAN, P. E. \& GEORGE-NASCIMENTO, M., 1978. Algunas relaciones entre el roedor Octodon degus y su carga parasitaria intestinal. Revista Iberica de Parasitologia, 38: 505-514.

CATTAN, P. E., GEORGE-NASCIMENTO, M. \& RODRIGUEZ, J., 1976. Primeras observaciones sobre las variaciones pobalacionales de los helmintos parasitos del roedor degu, Octodon degus. Boletin Chileno de Parasitologia, 31: 16-20.

CHABAUD, A. G., 1957. Specificité parasitaire chez les Nématodes parasites des vertébrés. In First Symposium on Host Specificity among Parasites of Vertebrates: 230-242. Neuchatel: Paul Attinger S.A.

CHABAUD, A. G., 1974. Keys to the subclasses, orders and superfamilies. In R. C. Anderson, A. G. Chabaud \& S. Willmott (Eds), No. I CIH Keys to the Nemaiode Parasites of Vertebrates. Farnham Royal, England: Commonwealth Agricultural Bureaux.

CHABAUD, A. G., 1978. Keys to genera of the superfamilies Cosmocercoidea, Seuratoidea, Heterakoidea and Subuluroidea. In R. C. Anderson, A. G. Chabaud \& S. Willmott (Eds), No. 6. CIH Keys to the Nematode Parasites of Vertebrates. Farnham Royal England: Commonwealth Agricultural Bureaux.

CHAPPILL, J. A., 1989. Quantitative characters in phylogenetic analysis. Cladistics, 5: 217-234.

CONTRERAS, L. C., TORRES-MURA, J. C. \& YANEZ, J. L., 1987. Biogeography of octodontid rodents: an eco-evolutionary hypothesis. In B. D. Patterson \& R. M. Timm (Eds), Studies in neotropical mammalogy, essays in honor of Philip Herschkovitz. Fieldiana Zoology, 39: 401-411.

COOK, J. A., ANDERSON, S. \& YATES, T. L., 1990. Notes on Bolivian mammals 6. The genus ctenomys (Rodentia, Ctenomyidae) in the highlands. American Museum Novifates, 2980: $27 \mathrm{pp}$.

CRESSEY, R. F., COLLETTE, B. B. \& RUSSO, J. L., 1983. Copepods and scombrid fishes: A study in hostparasite relationships. Fishery Bulletin, 81: 227-263.

DOWLING, T. E. \& BROWN, W. M., 1989. Allozymes, mitochondrial DNA, and levels of phylogenetic resolution among four minnow species (Notropis: Cyprinidae). Systematic Zoology, 38: 126-143.

DURETTE-DESSET, M.-C., 1971. Essai de classification des nématodes héligmosomes. Corrélations avec la paléobiogéographie des hôtes. Mémoires du Muséum National d'Histoire Naturelle, Paris, Série A. Zoologie, 69: $1-126$.

FAGERHOLM, H.-P., 1982. Nematode length and preservatives. Workshop: ICOPA V. Technology as applied to museum parasite collections. In M. Müller, W. Gutteridge \& P. Köhler (Eds), Parasites-their World and Ours. Abstracts of the Fifth International Congress of Parasitology. Amsterdam: Elsevier Biomedical Press.

FARRIS, J. S., 1990. Phenetics in camouflage. Cladistics, 6: 91-100.

FARRIS, J. S., 1989. The retention index and the rescaled consistency index. Cladistics, 5: 417-419.

GARDNER, S. L., 1984. Helminth parasites of Thomomys bulbivorus (Rodentia: Geomyidae), with the description of a new species of Hymenolepis (Cestoda). Canadian Journal of Zoology, 63: 1463-1469.

GORMAN, G. C. \& RENZI, J. JR., 1979. Genetic distance and heterozygosity estimates in electrophoretic studies: effects of sample size. Copeia, 1979: 242-249.

HUGOT, J. P., 1988. Les Nématodes Syphaciinae, parasites de rongeurs et de lagomorphes. Taxonomie, Zoogéographie, Évolution. Mémoires du Muséum National d'Histoire Naturelle. Série A. Zoologie, 141: 94-120.

HUMPHRIES, C. J., COX, J. M. \& NIELSEN, E. S., 1986. Nothophagus and its parasites: a cladistic approach to coevolution. In A. R. Stone \& D. L. Hawksworth (Eds), Coevolution and Systemaitcs: 55-75. Oxford: Clarendon Press.

KETHLEY, J. B. \& JOHNSTON, D. E., 1975. Resource tracking patterns in bird and mammal ectoparasites. Miscellaneous Publications of the Entomological Society of America, 9: 231-236.

KHALIL, M. \& VOGELSANG, E. G., 1931a. Paraspidodera americana n. sp. parasitic in a South American rodent. Zeitschrift für Parasitenkunde, 3: 142-144.

KHALIL, M. \& VOGELSANG, E. G., 1931b. On a new species of Paraspidodera, P. uruguaya sp. n. Zeilschrift für Parasitenkunde, 3: 145-147.

KIM, K. C., 1985. Parasitism and coevolution, cpilogue. In K. C. Kim (Ed.), Coevolution of Parasitic Arthropods and Mammals: 661-682. New York: John Wiley and Sons.

KLASSEN, G.J. \& BEVERLY-BURTON, M., 1988. North American fresh water ancyrocephalids (Monogenea) with articulating haptoral bars: Host-parasite coevolution. Systematic Zoology, 37: 179-189.

KLUGE, A. G. \& FARRIS, J. S., 1969. Quantitative phyletics and the evolution of anurans. Systematic Zoology, 18: 1-32.

KLUGE, A. G., 1989. A concern for evidence and a phylogenetic hypothesis of relationships among Epicrates (Boidae, Serpentes). Systematic Zoology, 38: 7-25.

LAVOCAT, R., 1974. What is an hystricomorph? Symposium of the Zoological Society of London, 34: 7-20.

LENT, H. \& DE FREITAS, J. F. 'T., 1939. Some remarks on the genus Paraspidodera Travassos, 1914 (Nematoda: Subulroidea). Volumen Jubilare Professor Sado Yoshida, 2: 273-278.

LESLIE, J. F., CAIN, G. D., MEFFE, G. K. \& VRIJENHOEK, R. G., 1982. Enzyme polymorphism in Ascaris suum (Nematoda). Journal of Parasitology, 68: 567-587.

MADDISON, W. P., DONOGHUE, M. J. \& MADDISON, D. R., 1984. Outgroup analysis and parsimony. Systematic Zoology, 33: 83-103.

MARES, M. A. \& OJEDA, R. A., 1982. Patterns of diversity and adaptation in South American hystricognath rodents. In M. A. Mares \& H. H. Genoways, (Eds), Mammalian Biology in South America (Special Publication), Pymatuning Laboratory of Ecology, Vol 6: 393-432. Pittsburgh: The Pymatuning Symposia in Ecology, University of Pittsburgh. 
MARES, M. A. \& WOODS, C. A., 1982. Family Gtenomyidae. In J. H. Honacki, D. E. Kinman \& J. W. Koeppel (Eds), Mammal Species of the World: 582-585. Lawrence, Kansas: Allen Press and The Association of Systematics Collections.

MARSHALL, L. G., 1988. Land mammals and the great American interchange. American Scientist, 76: 380-388.

MICKEVICH, M. F. \& JOHNSON, M. S., 1976. Congruence between morphological and allozyme data in evolutionary inference and character evolution. Systematic Zoology, 25: 260-270.

MICKEVICH, M. F. \& MITTER, C., 1981. Treating polymorphic characters in systematics: A phylogenetic treatment of electrophoretic data. In V. A. Funk \& D. R. Brooks (Eds), Advances in Cladistics. Proceedings of the First Meeting of the Willi Hennig Society: 46-58. New York: The New York Botanical Garden.

MITTER, C. \& BROOKS, D. R., 1983. Phylogenetic aspects of coevolution. In D. J. Futuyma \& M. Slatkin (Eds), Coevolution: 65-98. Sunderland, Mass.: Sinauer Associates Inc.

NEVO, E., 1979. Adaptive convergence and divergence in subterranean mammals. Annual Review of Ecology and Systematics, 10: 269-308.

O'GRADY, R. T. \& DEETS, G. B., 1987. Coding multistate characters, with special reference to the use of parasites as characters of their hosts. Systematic Zoology, 36: 268-279.

OSCHE, G., 1956. Unterschungen über die Morphologie vor allem des Lippenapparates von Paraspidodera uncinata (Nematoda) aus dem Meerschweinchen. Ein Beitrag zur Phylogenese zusammengesetzter komplex Organe (Synorganisation). Zeitschrift für Morphologie und Oekologie der Tiere, 45: 250-274.

PATTERSON, B. \& PASCUAL, R., 1972. The fossil mammal fauna of South America. Quarterly Reviewe of Biology, 43: 409-451.

PIMENTEL, R. A. \& SMITH, J. D., 1986. Bio tat II. A Multivariate Statistical Toolbox. Placentia, CA: Sigma soft.

REDUKER, D. W., DUSZYNSKI, D. W. \& YATES, T. L., 1987. Evolutionary relationships among Eimeria spp. (Apicomplexa) infecting cricetid rodents. Canadian Journal of Zoology, 65: 722-735.

REIG, O. A., 1986. Diversity patterns and differentiation of high andean rodents. In F. M. Vuilleumier \& M. Monasterio (Eds), High Altitude Tropical Biogeography: 404-439. New York: Oxford Lniversity Press.

REIG, O. A. \& KIBLISKY, P., 1969. Chromosome multiformity in the genus Ctenomys (Rodentia, Octodontidae). A progress report. Chromosoma, 28: 211-244.

REIG, O. \& SPOTORNO, A., 1972. A preliminary survey of chromosomes in populations of the chilcan burrowing octodont rodent Spalacopus cyanus Molina (Caviomorpha, Octodontidae). Biological Journal of the Linnean Society, 4: 29-38.

RIBEIRO, P. B., COSTA, P. R. P., MÜLLER, G. \& WIEGAND, M. M., 1985. Paraspidodera uncinala (Rud., 1819) Travassos, $1914 \mathrm{em}$ Cavia procellus no Município do Capao do Leao, Rio Grande do Sul, Brasil. Arquivos Brasileiros Medicina Veterinária Zoolechnica, 37: 377-379.

RICHARDSON, B. J., BAVERSTOCK, P. R. \& ADAMS, M., 1986. Allozyme electrophoresis: A Handbook for Animal Systematics and Population Studies. New York: Academic Press.

SAGE, R. D., CONTRERAS, J. R., ROIG, V. G. \& PATTON, J. L., 1986. Genetic variation in the South American burrowing rodents of the Ctenomys (Rodentia: Ctenomyidae). Zeitschrift für Säugetierkunde, 5l: $158-172$.

SARICH, V. M. \& CRONIN, J. E., 1981. South American mammal molecular systematics, evolutionary clocks, and continental drift. In R. L. Ciochon \& A. B. Chiarelli (Eds), Evolutionary Biology of New World Monkeys and Continental Drift: 347-368. New York: Plenum Press.

SIMPSON, G. G., 1980. Splendid Isolation. The Curious History of South American Mammals. Hew Haven: Yale University Press.

SKRIABIN, K. I., 1951. Key to Parasitic Nematodes. Volume 2: Oxyurata and Ascaridata: 255-277. New Delhi: Amerind Publishing Co. Pvt. Ltd.

SLAUGHTER, B. H. \& UBELAKER, J. E., 1984. Relationships of South Amcrican cricetines to rodents of North America and the old world. Journal of Vertebrate Paleontology, 4: 225-264.

SWOFFORD, D. L., 1985. PALP_-Phylogenetic Analysis Using Parsimony. Version 2.4.1, Champaign, Ill.: Illinois Natural History Survey.

SWOFFORD, D. L. \& SELANDER, R. K., 1981. Biosys-1: a computer program for the analysis of allelic variation in genetics. Urbana, Ill.: Department of Genetics and Development, University of Illinois.

SWOFFORD. D. L. \& BERLOCHER, S. H., 1987. Inferring evolutionary trees from gene frequency data under the principle of maximum parsimony. Systematic Zoology, 36: 293-325.

THORPE, R. S., 1984. Coding morphometric characters for constructing distance wagner networks. Evolution, 38: $244-255$.

VICENTE, J. J., GOMES, D. C. \& FILHO, N. A., 1982. Alguns helmintos de marsupias e roedores da ilha grande estado do Rio de Janiero. Atas da Sociedade de Biologia do Rio de Janeiro, 23: 3-4.

VILLARROEL, C. A., 1975. Dos nuevos Ctenomyidae (Caviomorpha, Rodentia) en los estratos de la formacion Umala (Plioceno superior) de Vizcachani (Prov. Aroma, Dpto. La Paz, Bolivia). Actas del Primer Congreso Argentino de Paleontologia y Bioestratigrafia Tucumán, 12-16 August, 1: 495-503.

WATROUS, L. E. \& WHEELER, Q. D., 1981. The outgroup comparison and method of character analysis. Systematic Zoology, 30: 1-11.

WERTHEIM, G. \& CHABAUD, A. G., 1977. Scanning electron microscopy of the cephalic structures of 
Pneumospiruridae: (Thelazioidea-Nematoda) Revision of the family. Annales de parasitologie Humaine et Comparée, 52: 647-657.

WOOD, A. E. \& PATTERSON, B., 1959. The rodents of the Deseadan Oligocene of Patagonia and the beginnings of South American rodent evolution. Bulletin of the Museum of Comparative Zoology, 120: $281-428$.

WOODS, C. A., 1982. The history and classification of South American hystricognath rodents: reflections on the far away and the long ago. In M. A. Mares \& H. H. Genoways (Eds), Mammalian Biology in South America (Special Publication), Pymatuning Laboratory of Ecology, Vol 6: 377-392. The Pymatuning Symposia in Ecology, Pittsburgh: University of Pittsburgh.

YATES, T. L. \& GREENBAUM, I. F., 1982. Biochemical systematics of North American moles (Insectivora: Talpidae). Journal of Mammalogy, 63: 368-374.

\section{APPENDIX 1}

HOST OTUS (CTENOMYIDAE). The following is a list of OTUs from which individuals were examined. All specimens (except outgroups) are housed in the Division of Mammals, Museum of Southwestern Biology (MSB), The University of New Mexico (UNM) or the Department of Mammalogy, American Museum of Natural History (AMNH). Information in parentheses indicate OTU designation and sample sizes, respectively. All individuals of Ctenomys used in this study were collected in Bolivia. Specimens examined: Ctenomys boliviensis goodfellowi Thomas Santa Cruz: $10 \mathrm{~km}$ N San Ramón, La Laguna (3); C. b. boliviensis Waterhouse Santa Cruz: $3.5 \mathrm{~km}$ W Estación el Pailón (14); C. b. boliviensis Santa Cruz: Estancia Cachuela Esperanza and San Miguel Rincon (8); C. b. boliviensis Santa Cruz: South of Santa Cruz de la Sierra (68); C. steinbachi Thomas Santa Cruz: $6 \mathrm{~km}$ N. Buen Retiro, near San Rafael de Amboró, and near Buena Vista (40); C. conoveri Osgood Chuquisaca: $9.7 \mathrm{~km}$ by road E of Carandyti (4); C. leweisi Thomas Tarija: $1 \mathrm{~km} \mathrm{E}$ Iscayachi (14); C. opimus Wagner, Oruro: Huancaroma (29); C. opimus, Oruro: $5 \mathrm{~km} \mathrm{W;} 1 \mathrm{~km}$ N Pomata Ayte, Rio Barros (11); C. opimus Wagner Oruro: Cruce Ventilla (8); C. frater Thomas, Tarija: Rancho Tambo (7). HOST OUTGROUPS (OCTODONTIDAE): Aconaemys fuscus (Waterhouse). ARGENTINA: Neuquén: (Ruca Malén), Lago correntoso (4); Oclodon degus (Molina). CHILE: Santiago Province, $8 \mathrm{~km}$ W Tiltil (4); Spalacopus cyanus (Molina). CHILE: Santiago Province, $3 \mathrm{~km}$ NW Calev (3).

PARASITE OTUS (HETERAKOIDEA): Those specimens of Paraspidodera from an individual host that were assayed using electrophoresis are indicated with an asterisk. Those specimen numbers of Paraspidodera sp. that were studied are listed below, one NK number may represent 20 or more individual male and female nematodes. The name of the host OTU is listed first followed by collection locality and field and laboratory 'NK' numbers or museum or personal catalogue numbers. Parasite OTUs are indicated by abbreviations of the host species or locality names. Nematodes used as outgroups are also listed and are so indicated. All specimens of nematodes collected in Bolivia and used in this study are retained in the 'Bolivia Parasite Collection' of S. L. Gardner (UCDNC) (U.C. Davis). Specimens of parasites to be used for future electrophoretic or biochemical analysis are stored in the frozen tissue collection of (UCDNC) U. C. Davis. Representative voucher specimens of specific taxa will be deposited in the USNM helminthological collection. Individuals of several taxa of parasites were borrowed from various institutions (listed below) for use in outgroup comparisons. In the following list ' $N K$ ' refers to the 'New Mexico Karotype' field number established for each mammal specimen and their associated parasites; 'SG' refers to S. Gardner, my personal field-note catalogue specimen number; 'USNM' refers to the United States National Museum catalogue number; 'NHMP' refers to the catalogue number of the Muséum National D'Histoire Naturelle, Laboratoire Des Vers, Paris; 'PYGEN' refers to the catalog number of Muséum National D'Histoire Naturelle, Laboratoire Des Vers, Geneva.

NEMATODE PARASITES: Parasites specimens examined. Host species is listed first, followed by collection locality, OTU abbreviation, and specimen numbers: Ctenomys boliviensis boliviensis. BOLIVIA: Santa Cruz: Estancia Cachuela Esperanza, Estación El Pailón, and south of Santa Cruz de la Sierra. [PBOLBOL, Nk Numbers: NK 1 1686, NK $11687,{ }^{*}$ NK1 1691, NK11869, NK,1 1872, NK 11873 , NK12281, NK15064]. Clenomys boliviensis goodfellowi. BOLIVIA: Santa Cruz: $10 \mathrm{~km}$ N San Ramón, La Laguna. [PBOLGFE, NK Numbers: *NK 13029, NK13031]. Ctenomys conoveri. BOLIVIA: Chuquisaca: $9.7 \mathrm{~km}$ by road E of Carandyti. [PCONOVE; NK numbers: NK 12573, NK12606, *NK12607, *NK12614]. Ctenomys frater. BOLIVIA: Tarija: $8 \mathrm{~km}$ W Rancho Tambo. [PFRATER: NK14613, *NK 14621, *NK 14622, NK 14623]. Ctenomys lewisi. BOLIVIA: Tarija: $1 \mathrm{~km}$ E. Iscayachi. [PLEWISI: NK14668, NK14669, *NK14688, NK 14709, NK14652, NK 14719]. Ctenomys steinbachi. BOLIVIA: Santa Cruz: $6 \mathrm{~km}$ N Buen Retiro, near San Rafael de Amboró, and near Buena Vista. [PSTEINB: NK15232, NK12922, *NK12944, NK15218, NK15231]. Ctenomys opimus. BOLIVIA: Oruro: Huancaroma. [POPIMHU: *NK11513, NK11517, NK11551, NK11565, NK14766]. C. opimus. BOLIVIA: Oruro: $5 \mathrm{~km} \mathrm{W;} 1$ km N Pomata Ayte, Rio Barros. [POPIMRB: *NK 14557, NK 14547, NK14561]. Parasite outgroups, morphologic study: Cavia sp. Collection locality unknown. [PCAVIASP: USNM66132, USNM42585, USNM69819]. Cavia procellus. Parasite species: Paraspidodera uncinata (Rudolphi, 1819). VENEZUELA: Marcay. [PHYPANC: NHMP 737F]. Cavia aperea. Parasite species: Paraspidodera uncinata. PARAGUAY. [PCAVAPE: FNM534HA10] Parasite outgroups for electrophoretic study: Jungle fowl, domestic, free roaming, near Albuquerque, NM. Heterakis sp. Dujardin, 1845. HE TERAK *SG-21-86. Jungle fowl, free roaming, near Albuquerque, NM. Ascaridia galli (Schrank, 1788) [*SG2-88, *SG4-88]. 


\section{APPENDIX 2}

Character-state data for qualitative and quantitative characters for species of the genus Ctenomys and outgroups used to construct the tree in Fig. 7. The first nine (1-9) and last two (25-26) characters are qualitative characters, defined in Table 3. See Figs 5, 6 for illustrations of the following skull characters. Characters and character states are defined as follows: [1] Postorbital process: $0=$ absent, $1=$ small process, $2=$ medium process, $3=$ well defined and large process; [2] Process of zygomatic arch: $0=$ one point very reduced, directed posteriad, $1=$ one point, more defined, directed anteriad, $2=$ large well developed point, $3=$ two points, complex; [3] Curvature of zygomatic process: $0=$ straight, $1=$ rounded, $2=$ very round; [4] Articulation surface on coronoid process: $0=$ completely reduced, $l=$ very small surface, $2=$ small angle on surface, 3 = larger surface, not horizontal, $4=$ horizontal surface with large area; [5] Roots of top incisors: $0=$ not embedded, free to side of 2 nd molar; $1=$ well embedded, root above lst molar root; $2=$ well embedded origin at side and origin of $1 \mathrm{st}$ and 2 nd molars, respectively; 3 = less well embedded, origin at middle of 2 nd molar; $4=$ well embedded, origin at side of 2 nd molar; [6] Hole in presphenoid bone: $0=$ absent, $1=$ elongate, $2=$ medium round, $3=$ small to minute, $4=$ large; [7] Incisive foramen: $0=$ two holes, $1=$ one hole; [8] Ridge and suture of parietal bone: $0=$ completely congruent, 1 = partially congruent, $2=$ no ridge present. Characters $9-24$ represent gap-coded quantitative data. All characters except 20 (dental span) and 23 (interorbital breadth) were used to construct the cladogram in Fig. 7). See Fig. 5 for illustrations of the following skull characters. Characters 9-24 are defined as follows: [9] Total length of body: $0=$ shortest, $3=$ longest; [10] Length of tail: $0=$ shortest, $4=$ longest; [1 l] Length of hind foot: $0=$ shortest, $4=$ longest; [12] Pinna length: 0 = shortest, 5 =longest; [13] Body weight: $0=$ lightest, $3=$ heaviest; [14] Condylobasalar lenght: $0=$ shortest, 3 =greatest; [15] Condyloinscisive length: $0=$ shortest, $4=$ greatest; [16] Palatal length: $0=$ shortest, 4 = greatest; [17] Molar tooth row length: $0=$ shortest, $5=$ longest; [18] Palatal breadth: $0=$ shortest, $1=$ longest; [19] Dental span: $0=$ narrowest, $5=$ greatest width; [20] Zygomatic breadth: 0 = narrowest, $4=$ greatest breadth; [21] Lambdoidal breadth: $0=$ narrowest, 4 = greatest breadth; [22] Interorbital breadth: 0 = narrowest, $3=$ greatest breadth; [23] Skull height: $0=$ lowest, $2=$ greatest height. Chromosomes of the ingroup and the outgroup were coded as follows: [24] Diploid number: $0=10-25,1=26-40,2=41-55,3=56-70$; [25] Fundamental number: $0=16-46, \quad 1=47-76, \quad 2=77-100,3=101-130 ; \quad[26] \mathrm{Y}$ chromosome size: $0=$ small, $\quad 1=$ larger, $2=$ medium, $3=$ large.

\section{APPENDIX 3}

Character-state data for qualitative and quantitative characters for species of the genus Paraspidodera used to construct trees in Fig 8 and 9. See Tables 4, 7 for reference to the following character definitions. This Appendix parallels the information in Table 7: the first 24 (characters 1-24) are quantitative gap-coded characters of males only, the next 5 (characters 25-29) are qualitative characters, the next 13 (characters 30-42) are quantitative characters of the females, the last 13 characters are allozymic characters as given in Table 6. [1] Length of oesophagus: $0=$ shortest, $3=$ longest; [2] Distance of excretory pore to anterior end: $0=$ shortest, 2 = greatest; [3] Left spicule length: $0=$ shortest, $4=$ longest; [4] Right spicule length: $0=$ shortest, $4=$ longest; [5] Distance of nerve ring to anterior end: $0=$ shortest, $2=$ greatest; [6] Width of oesophageal bulb: $0=$ narrowest, $4=$ widest; [7] Length of oesophageal bulb: $0=$ shortest, $4=$ longest; [8] Minimum width of oesophagus bulb: $0=$ minimum width, $3=$ maximum width; [9] Width of head: $0=$ minimum, 4 = maximum; [10] Length of head: 0 = minimum, 2 = maximum; [11] Length of tail: $0=$ shortest, $3=$ longest; [12] Left spicule maximum width: $0=$ minimum, $3=$ maximum; [13] Left spicule width (minimum): $0=$ minimum, 2 = maximum; [14] Left spicule width, proximal end: $0=$ minimum, $2=$ maximum: [15] Left spicule proximal tip length: $0=$ shortest, $3=$ longest: [16] Right spicule maximum width: $0=$ minimum, $3=$ maximum: [17] Right spicule minimum width: $0=$ minimum, $3=$ maximum: [18] Right spicule width, proximal end: $0=$ minimum, $1=$ maximum; [19] Right spicule length proximal end: $0=$ shortest, $3=$ longest; [20] Length of gubernaculum: $0=$ shortest, $6=$ longest; [21] Maximum width of gubernaculum: $0=$ minimum $2=$ maximum; [22] Blade of gubernaculum, maximum width: 0 minimum, 3 = maximum; [23] Inside diameter of gubernaculum: $0=$ minimum, $4=$ maximum; [24] Length of blade of gubernaculum: $0=$ shortest, $5=$ longest. The following 5 characters are qualitative. [25] Shape of lateral alae: $0=$ low and pointed, $1=$ low and rounded, 2 = boxlike and medium height, $3=$ high and well developed; [26] Height of lateral alae: $0=$ very short, $1=$ medium height, $2=$ very high; [27] Development of excretory ducts: $0=$ minimum development, $1=$ well developed; [28] Larvae present or absent in eggs in uterus: $0=$ absent, $1=$ present; [29] Degree of interdigitization of lips on head: $0=$ none, $1=$ moderate, $2=$ well developed. The next 13 characters are from female nematodes only. [30] Total length of: $0=$ shortest, 4 = longest; [31] Length of oesophagus: $0=$ shortest, $2=$ longest; [32] Width of oesophageal bulb: $0=$ minimum, $6=$ maximum; [33] Length of oesophageal bulb: $0=$ shortest, $4=$ longest; [34] Minimum width of oesophageal bulb: $0=$ minimum, $7=$ maximum; [35] Distance of nerve ring to anterior end: $0=$ shortest, 2 = greatest; [36] Distance of excretory pore to anterior end: $0=$ shortest, $4=$ greatest; [37] Length of stoma: $0=$ shortest, $2=$ longest; [38] Length of head: $0=$ shortest, $2=$ longest; [39] Length of tail: $0=$ shortest, $3=$ longest; [40] Width at anus: $0=$ narrowest, 2 = widest; [41] Length of egg: $0=$ shortest, $5=$ longest; [42] Width of egg: $0=$ narrowest, $6=$ widest. See Tables $4,6,7$ for coding of characters $43-55$. 